\title{
Estudo exploratório sobre filiação e identificação partidária no Brasil
}

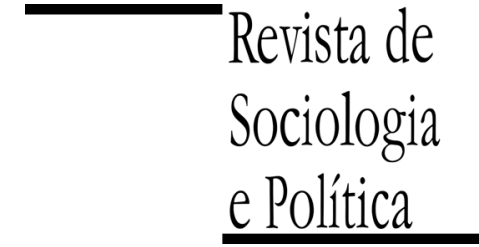

DOI 10.1590/1678-987315235606

\author{
Bruno Wilhelm Speck, Maria do Socorro Sousa Braga \\ e Valeriano Costa
}

\begin{abstract}
Resumo
O artigo recupera a discussão dos conceitos de filiação partidária e identificação partidária na Ciência Política contemporânea e analisa os respectivos dados a partir dos resultados do Estudo Eleitoral Brasileiro (ESEB) de 2014. Analisamos os dados sobre a filiação partidária e a identificação partidária, primeiro através de inferências descritivas a respeito da distribuição das variáveis na amostra do ESEB, depois avaliando o poder explicativo das variáveis para entender diferentes dimensões do comportamento e das atitudes políticas dos entrevistados. Identificamos três tipos de filiados: (i) os filiados sem empatia por um partido; (ii) os que tem empatia pelo partido ao qual estão filiados (50\%) e (iii) os que apresentam empatia por um outro partido. Esses resultados indicam a necessidade de explorar diferentes dimensões da filiação partidária em futuras pesquisas. Em relação à identificação partidária, verificamos que ela contribui para explicar a probabilidade de filiação e de se engajar em diferentes formas de ativismo político. A variável identificação partidária também ajuda prever o comparecimento eleitoral. Os fenômenos da filiação partidária e da identificação partidária, pouco valorizados na Ciência Política brasileira, apresentam padrões consistentes e são ferramentas importantes para entender o comportamento político dos cidadãos. Futuras pesquisas devem dedicar mais atenção a esses fenômenos.
\end{abstract}

PALAVRAS-CHAVE: filiação partidária; identificação partidária; partidos políticos; participação política; Estudos eleitorais.

Recebido em 21 de Maio de 2015. Aceito em 23 de Setembro de 2015.

\section{Introdução ${ }^{1}$}

\begin{abstract}
1 Esse artigo é resultado do projeto temático Organização e funcionamento da política representativa do estado de São Paulo (1994 e 2014), desenvolvido por professores da UFSCar, UNICAMP e USP, com financiamento da Fapesp (projeto n. 2012/19330-8). Agradecemos aos pareceristas anônimos da Revista de Sociologia e Política pelas críticas e sugestões.
\end{abstract}

\footnotetext{
2 No ESEB 2014, realizado poucas semanas depois do pleito de 2014 , somente $70,9 \%$ dos entrevistados souberam informar a sigla do partido pelo qual votaram para presidente no primeiro turno. Em relação aos outros cargos essas porcentagens são menores: governador $(54,0 \%)$,
}

A maior parte da literatura acadêmica diagnostica o vínculo entre os partidos políticos e o eleitorado brasileiro como fraco. A conturbada tradição de diferentes sistemas partidários ao longo da história brasileira e a dificuldade de associar as divisões partidárias a clivagens sociais ou ideológicas são alguns dos fatores arrolados para explicar porque os partidos não contam com eleitores fiéis (Soares 1982). A proliferação de siglas partidárias desde a volta ao multipartidarismo, a partir de 1980, e as altas taxas de fragmentação e migração partidárias seriam sintomas desses laços fracos entre partidos e sociedade. A curta tradição das organizações partidárias e o número elevado de siglas dificultaria a criação de vínculos estáveis entre eleitorado e partidos que caracteriza outras democracias representativas (Kinzo 2005). Finalmente, as pesquisas eleitorais indicam que os partidos políticos têm um papel periférico no imaginário político. Poucas semanas após o pleito somente uma pequena fração dos votantes se lembra em qual partido votou na última eleição².

Todos esses indícios são usualmente arrolados para fundamentar a tese da relevância limitada dos partidos políticos para estruturar as opiniões e ações do eleitorado brasileiro. Por outro lado, confrontamos o fato de que os eleitores reconduzem os partidos políticos aos cargos mais altos aproximadamente na mesma proporção dos pleitos passados. A identificação com partidos políticos no eleitorado é baixa, mas ela é significativa para partidos políticos de esquerda. Finalmente, um dos enigmas do sistema partidário brasileiro são as altas taxas 
senador $(30,1 \%)$, deputado federal $(6,2 \%)$, deputado estadual $(5,6 \%)$. A porcentagem de votos válidos para esses respectivos cargos é mais alta. de filiação partidária. Aproximadamente um em cada 10 cidadãos está oficialmente filiado a algum partido político. Na comparação internacional o país figura entre as democracias com as maiores taxas de filiação ${ }^{3}$.

O presente artigo explora a questão dos vínculos entre eleitorado e partidos políticos no Brasil dialogando com duas tradições diferentes de pesquisa: primeiro, a discussão sobre as organizações partidárias e o papel dos ativistas filiados aos partidos, que se insere numa linha de pesquisas iniciadas por Duverger; segundo, as pesquisas eleitorais na linha iniciada pela Escola de Michigan, que explora o conceito da identificação partidária dos cidadãos comuns para entender atitudes e comportamentos dos eleitores. O ESEB $2014^{4}$ incluiu perguntas que permitem explorar e comparar o valor heurístico de ambos os conceitos para entender as atitudes e comportamentos políticos dos cidadãos.

\section{I.1. Duverger e os filiados: centro gravitacional do partido de massa}

${ }^{3}$ Segundo um estudo de Biezen, Mair e Pogundke (2011) sobre a filiação partidária em 27 democracias da Europa a taxa média de filiação partidária (porcentagem de filiados sobre o eleitorado) é de $4,7 \%$ (dados referentes aos anos 2004 a 2009). As maiores taxas de filiação encontram-se na Áustria (17,3\%), os menores em Latvia $(0,7 \%)$.

${ }^{4}$ O ESEB 2014 foi aplicado a uma amostra nacional de 3.136 eleitores com um nível de confiança estimado em 95\% e margem de erro máxima estimada em $2 \%$ (dois) pontos percentuais para mais ou para menos sobre os resultados encontrados no total da amostra.

\footnotetext{
${ }^{5}$ Uma primeira pista para analisar as atividades desenvolvidas pelos filiados está disponível a partir da pesquisa sobre filiados partidários no Estado de São Paulo (realizada em 2014). Os dados ali revelam que somente $25,5 \%$ dos filiados pagam contribuições regulares.
}

A questão da filiação a partidos políticos no Brasil é especialmente intrigante. As taxas altas de filiação contrastam com a ausência de uma tradição de pesquisa sobre o fenômeno. A filiação é tradicionalmente associada a várias manifestações do ativismo político em organizações partidárias que compreendem o engajamento em campanhas eleitorais, a participação em mobilizações do partido ou a disputa de cargos em nome do partido político, entre outras atividades. Nessa gama de comportamentos e atitudes dos ativistas e simpatizantes dos partidos a filiação se destaca pela formalização e a regularidade do compromisso assumido com o partido.

A pesquisa acadêmica sobre o Brasil até recentemente ignorou os dados sobre a filiação formal de cidadãos a partidos políticos (Speck 2013). Mesmo que as razões dessa omissão não sejam explicitadas, tudo leva a crer que, na concepção dos pesquisadores, a filiação partidária no Brasil não corresponderia aos padrões, supostamente universais, dos partidos de massa da Europa Ocidental. Na tradição da análise de Duverger (1987), os partidos de massa merecem esse nome justamente porque formalizaram a relação com os seus simpatizantes, tornando-os membros pagantes da organização partidária que, assim, ganharam autonomia e fôlego financeiro. Com isso, capacitaram-se para financiar campanhas eleitorais, permitindo a profissionalização da atividade política também entre os partidos socialistas cujos ativistas não dispunham de recursos próprios para um engajamento político sem remuneração. Por essas raízes históricas, a filiação formal estaria intrinsecamente vinculada ao pagamento regular de contribuições.

Pelo pouco que sabemos, pois os dados ainda são escassos ${ }^{5}$, a maioria dos filiados aos partidos brasileiros não costumam pagar anuidades, exceto quando ocupam cargos públicos de livre comissionamento. A filiação partidária seria um mero ato formal, desprovido de sentido e conteúdo e, portanto, de pouco interesse para a pesquisa acadêmica.

Em contraste com essa tradição de pesquisas, achamos prudente não descartar de antemão a filiação partidária no Brasil como desprovida de significado só porque ela não apresenta as mesmas conotações e correlações com outros padrões de comportamento político. Se os filiados não pagam contribuições regulares, isso não significa que a sua filiação seja um ato aleatório. Essa reavaliação da filiação partidária também dialoga com publicações mais recentes sobre o significado da filiação partidária em outros países. Pesquisas recentes sobre filiação partidária mostraram que os significados e os formatos da filiação partidária se multiplicaram nas últimas décadas (Scarrow 2015; Van Haute et al., 2015), afetando, também, o próprio formato organizacional dos 
partidos. O formato clássico dos partidos de massa estaria cedendo lugar aos partidos de público (Manin 2013).

\section{I.2. A Escola de Michigan e a identificação partidária: atitudes perenes do eleitor comum}

As investigações sobre o comportamento eleitoral novamente colocaram os partidos no centro da atenção quando os estudos da Escola de Michigan, nos anos 1950, desenvolveram modelos causais para entender por que os eleitores votam em determinados partidos e não em outros. Um dos paradoxos básicos que exigiam explicação foi a relativa continuidade do comportamento eleitoral apesar da constante mudança nos fatores individuais, nos contextos socioeconômicos e nas avaliações dos cidadãos em relação aos candidatos. Para captar esse alinhamento do eleitorado norte-americano com os partidos políticos, que se manifesta em escolhas eleitorais relativamente consistentes e estáveis (eleitores votam em candidatos do mesmo partido em eleições para diferentes cargos e em pleitos subsequentes), a Escola de Michigan introduziu o conceito da identificação partidária. Segundo a definição clássica (Campbell et al., 1960), esse conceito capta um sentimento de proximidade do eleitor com determinado partido político que seria mais profundo do que avaliações conjunturais de partidos e governos. A identificação partidária seria produto da socialização política e representaria um conjunto de predisposições políticas e de atitudes básicas frente a partidos políticos que se mostrariam resistentes a influências conjunturais.

A ferramenta por excelência para medir a identificação partidária são as pesquisas de opinião. Como em relação a outros conceitos da cultura política, uma das dificuldades resulta da questão de operacionalização do conceito. $\mathrm{O}$ modelo de perguntas usado para aferir a identificação partidária envolve três passos: primeiro, identificar a existência ou não de identificação partidária; depois perguntar a respeito do partido em questão; por fim, inquirir a intensi-

${ }^{6}$ Um exemplo da sequência (tirado dos EUA) é: "De forma geral você se considera um republicano, um democrata ou independente?" (Thomassen 1994).

\footnotetext{
${ }^{7}$ A possibilidade de a identificação partidária também sofrer a influência desses fatores (sendo variável dependente) esteve teoricamente incluído no modelo, mas teve um papel secundário na investigação.
} dade dessa identificação ${ }^{6}$.

Desde a formulação inicial pela Escola de Michigan, a estabilidade, a intensidade e a consistência foram atributos importantes do conceito da identificação partidária. Uma das questões centrais era como a identificação partidária se relacionava com dados sobre o comportamento eleitoral (o comparecimento em eleições e o voto em determinados partidos), bem como com atitudes políticas ou avaliações de governos ou partidos políticos. A identificação partidária, em primeiro lugar, era vista como fator antecedente, portanto explicativo, para entender atitudes políticas, avaliações e comportamento eleitoral dos cidadãos ${ }^{7}$.

O conceito da identificação partidária teve ampla influência sobre as pesquisas eleitorais na Europa (Thomassen 1994) e, a partir das últimas duas décadas do século XX, as perguntas sobre a identificação partidária foram incorporadas às pesquisas de opinião pública realizadas com regularidade nesses países. $\mathrm{Na}$ América Latina, perguntas sobre a identificação partidária foram incluídas nas pesquisas do Latinobarômetro, do LAPOP e do World Value Survey. No Brasil, os dados sobre a identificação partidária foram explorados por vários pesquisadores nas suas análises sobre a relação entre eleitorado e partidos políticos.

\section{I.3. Diagnósticos sobre partidarismo dos eleitores no Brasil}

Desde a redemocratização vem ocorrendo intenso debate acerca da capacidade dos partidos políticos de serem tanto eficientes em manter a governabilidade democrática, como em estruturar as preferências eleitorais e, consequentemente, conseguirem construir suas identidades a partir da formação 
de orientações subjetivas dos eleitores em relação a eles próprios, criar lealdades e servirem como atores cruciais da competição eleitoral. Vale destacar que é no segundo aspecto que reside o maior pessimismo sobre a viabilidade de nossos partidos.

Entre os críticos, Kinzo e Braga (2007) argumentam que os partidos não conseguem ser eficientes na estruturação do voto, sugerindo que até o início desse século ainda não havia se estabelecido um padrão definitivo de apoio partidário no Brasil. Para isso lançaram mão do índice da volatilidade partidária que, embora mostrasse tendência de queda, foi avaliado como indicador da dificuldade da estabilização do sistema partidário. Para examinar os vínculos partidários, avaliaram ainda a variação longitudinal da preferência partidária para o período de 1989 a 2002, medido por pesquisas de opinião pública, encontrando o percentual médio de $46 \%$ de preferência por algum partido. Como em outros trabalhos (Carreirão \& Kinzo 2004), essa análise não examina o papel dos partidos no eleitorado como um todo, mas apenas a metade do corpo eleitoral que se diz identificar partidariamente. Entre os partidos, ressalta o crescimento significativo da preferência pelo PT, que passou de 10\%, em 1989, para $18 \%$, em 2002, constituindo-se no único partido de massas brasileiro. As causas dos fracos laços entre partidos e eleitores estariam relacionadas ao impacto da televisão na disputa eleitoral, ao centrar as campanhas em personalidades, em vez dos partidos, e à estrutura de incentivos formada por dois sistemas eleitorais, majoritário e proporcional, que contribuiriam para reduzir as distinções programáticas entre os partidos, dificultando a criação de identidades partidárias e a formação de conexões subjetivas com os eleitores. Para estes, como para outros analistas, a exceção nesse quadro seria o PT. Esse teria sido o único partido que conseguiu desenvolver importante identificação com parte do eleitorado (denominados, pela autora, de simpatizantes), o que teria ocorrido devido à exposição do partido de forma organizada e de sua estratégia de construir um perfil diferenciado, posicionando-se como um partido de oposição e de esquerda até chegar no governo federal em 2002.

Samuels (2008) investiga a origem da evolução das bases de apoio de massa do PT, verificando se o perfil do petista médio mudou entre as eleições de 2002 e 2008. Para isso compara os dados dos ESEB2002 e LAPOP 2007. Samuels chama de petista médio os "identificados" com o PT, portanto aqueles que declaram nos surveys examinados ter preferência pelo partido. Conclui que a ideologia de esquerda em 2007 deixou de predizer a identificação com o PT, o que para o autor revelaria que a moderação de sua elite teria influenciado sua base de massa. Supõe que essa moderação dos identificados com o PT tem origem no próprio recrutamento de novos apoiadores e na saída de antigos simpatizantes. Para ele, a base de apoio petista em 2007 apresenta o seguinte perfil: além de residir nos municípios mais desenvolvidos, acredita que o voto faz diferença na política, apresentam alta participação eleitoral e maior conhecimento político. Esses resultados levaram o autor a concluir que houve um baixo grau de mudança nas bases de apoio ao PT, tornando-se levemente moderadas e menos escolarizadas.

Todavia, Veiga (2007; 2011), Singer (2010; 2012) e Venturi (2010) também identificaram, no período entre 2002 e 2006, alteração na base do eleitorado petista por conta do menor índice de escolarização verificado na reeleição de Lula da Silva, redundando num processo de popularização do partido. Para Singer (2010; 2012), tal processo se iniciou antes mesmo das eleições de 2002, de modo que, nos períodos subsequentes, deu-se uma expansão dessa popularização. Entre outros fatores determinantes desse processo estariam a perda de simpatia da classe média pelo partido, bem como o apoio das classes mais populares em razão da implementação das políticas sociais pelo Governo Federal no período. 
Em outro sentido, estudos empíricos recentes focaram as condições favoráveis à identificação e que sentimentos positivos essas instituições despertam no eleitor. Entre esses trabalhos, Carreirão e Kinzo (2004), Veiga (2011) e Samuels e Zucco Jr. (2010) verificaram uma redução acentuada no percentual de identificados com o PMDB, enquanto PT e PSDB apresentaram crescimento ao menos até o pleito presidencial de 2010. Daí em diante a tendência observada foi de declínio para todos os partidos. Ao mesmo tempo, as pesquisas de opinião demonstravam o aumento acentuado dos eleitores sem preferência partidária, chegando a 68\% do eleitorado na pesquisa do Datafolha de outubro de 2014.

Para Carreirão e Kinzo (2004) essa queda na identificação partidária após a redemocratização estaria relacionada tanto ao papel que a televisão passou a ter nas campanhas eleitorais quanto ao aumento na escolaridade e a ampliação do acesso à informação através dos novos meios de comunicação, resultando que as novas gerações aumentassem sua capacidade de absorver as informações políticas, sem a necessidade de usar os partidos como atalhos de informação. Já Veiga (2011), ao analisar as oscilações presentes no período de 2002 a 2010, avalia continuidades e alterações no perfil dos eleitores partidários e verifica que em um curto período de tempo o perfil desses eleitores sofreu consideráveis alterações. O eleitor partidário, em 2010, encontrar-se-ia mais escolarizado que em 2006, residiria mais no Norte, Centro-Oeste e Nordeste e estaria mais próximo da centro-esquerda e centro-direita.

Já Braga e Pimentel Jr. (2011) defendem que os partidos são importantes para a explicação do comportamento eleitoral no Brasil. Para demonstrar a situação do partidarismo no Brasil, os autores compararam o cenário nacional e o internacional por meio de uma listagem das médias de identificação partidária de diversas democracias entre 1996 a 2000 e de 2000 a 2005. Revelaram que a conexão entre eleitores e partidos no Brasil, quando comparada a outras nações, não coloca os brasileiros em uma posição tão negativa quanto a defendida por estudiosos, já que o país encontra-se um pouco acima da média mundial, somando 49,5\% de 2000 a 2005. Ainda demonstram que em relação às democracias consolidadas, o Brasil se encontra muito próximo de países como Grã-Bretanha, Dinamarca, Noruega, Suécia, Finlândia e Irlanda e ainda possui percentuais superiores aos de Japão, Alemanha, Coréia do Sul, Bélgica e Holanda.

Como vimos, passados mais de 35 anos da criação dos nossos principais partidos não há consenso na bibliografia nacional sobre a sua capacidade de criar vínculos com o eleitorado, formar identidades partidárias cruciais para a estruturação das preferências eleitorais e, mesmo, atrair filiados que são fundamentais à sobrevivência do partido como organização. Esta última dimensão nem sequer foi levada em conta na maior parte dos estudos sobre o partidarismo no Brasil, o que revela a baixa importância que vem se dando à análise dessas variáveis organizacionais.

A partir daqui o artigo divide-se em três partes. Na primeira, exploramos as duas variáveis, filiação e identificação partidária, separadamente. Queremos explorar a presença dos cidadãos que se declaram filiados a partidos e aqueles que se identificam com partidos. A quais grupos ideológicos de partidos esses laços formais e ideacionais se dirigem? Em quais regiões estão presentes? Como se distribuem entre determinados segmentos da população? Na segunda, comparamos a intensidade e consistência da filiação e da identificação partidária, duas questões básicas em ambas as tradições de pesquisa às quais os dois conceitos estão vinculadas. Também perguntamos como os dois conceitos interagem com outras atitudes frente a partidos políticos e a temas políticos em geral. Na terceira, testamos o poder explicativo da filiação e identificação partidária para entender o comportamento eleitoral dos cidadãos entrevistados 
na última eleição em 2014. A ênfase do texto repousa claramente nas questões da segunda parte. Mais do que usar os conceitos de filiação e identificação, queremos testar até onde eles se mostram sólidos como ferramentas de análise.

\section{O perfil da filiação e identificação partidária}

Antes de entrar na questão do perfil dos filiados e simpatizantes dos partidos cabem alguns comentários de precaução em relação à forma como esses dados são produzidos. Ao levantar a informação sobre a filiação partidária por meio de pesquisas de opinião não captamos necessariamente uma amostra do grupo de cidadãos oficialmente filiados aos partidos políticos. Duas razões importantes para essa distonia são que o entrevistado pode não se lembrar ou não saber que é filiado, ou ele pode se sentir desconfortável durante a entrevista com a revelação da sua filiação a um partido. Trabalhos sobre outros países identificaram discrepâncias sistemáticas entre a filiação declarada e os registros de filiados nos partidos políticos (Scarrow \& Gezgor 2010). A diferença gira em média em torno de dois pontos percentuais entre os dados oficiais e as taxas de filiação apuradas nas pesquisas de opinião, o que representa uma diferença grande se levarmos em conta que as taxas oficiais de filiação giram em torno de $5 \%$ nas democracias consolidadas. Mas em alguns países as discrepâncias são maiores. Nos dados levantados pelos autores as maiores discrepâncias são encontradas na Suécia, com dados de pesquisa de opinião indicando $12 \%$ de filiados enquanto os partidos informam 8\% de filiados (1990), e na Áustria, com 13\% e $18 \%$ de filiados, respectivamente (2000). Normalmente, as taxas de filiação identificadas nas entrevistas estão acima dos dados oficiais.

No caso brasileiro, a distância entre as taxas oficiais de filiação (em torno de $11 \%$ do eleitorado, em 2014) e a proporção de filiados identificados no ESEB (3\%) indica um fenômeno similar, com duas diferenças importantes em comparação com os países analisados pelos autores citados. Primeiro, a discrepância é maior, alcançando oito pontos percentuais. Segundo, as pesquisas de opinião reportam taxas menores de filiação do que os números oficiais. Enquanto Scarrow e Gezgor (idem) especulam sobre a possibilidade de que a autoimagem dos cidadãos tende a superestimar o próprio ativismo, no Brasil poderíamos especular que os cidadãos são mais ativos politicamente do que a sua própria imagem lhes permite confessar. Outras possíveis explicações pela distância entre a taxa de filiação encontrada pelo ESEB e o dado oficial do TSE são a defasagem dos dados oficiais por falta de comunicação sobre a desfiliação de eleitores; a falta de atualização dos dados sobre a morte de filiados; filiados antigos que não são ativos há muitos anos podem não se lembram da sua condição de filiado; por fim, cidadãos podem ser registrados involuntariamente ou à revelia pelas lideranças partidárias.

A principio, nenhum dos dois dados - o registro oficial ou as informações dos entrevistados - pode ser usado para desacreditar o outro. Sendo dois universos diferentes é importante ressaltar que o universo dos filiados do ESEB são aqueles que se auto-identificaram como sendo filiados a um partido político.

Outra nota de precaução se faz necessária em relação aos dados da identificação partidária. Enquanto a filiação partidária destacada nas pesquisas sobre sistemas partidários se refere a um ato formal, a identificação partidária, oriunda das pesquisas sobre comportamento eleitoral, é um fenômeno abstrato que não pode ser observado diretamente. A suposição é que os eleitores disponham de uma predisposição interna de se identificar com determinado partido e que essa predisposição seja uma chave explicativa importante para entender padrões de atitudes e comportamentos políticos. Para operacionalizar a pesquisa sobre esse conceito os pesquisadores recorreram a diferentes estraté- 
${ }^{8}$ Para a questão da importância do wording em questionários captando fenômenos da cultura política, ver também Rennó (2011).
9 O artigo de Thomassen (1994) discute em detalhe o impacto de diferentes formas de explicitar essa identificação de uma disposição mais geral, com a finalidade de separar a identificação partidária de sentimentos mais conjunturais. gias para assegurar a perenidade, a profundidade e a consistência da identificação partidária. Pesquisas recentes mostraram que a exata formulação (wording) das perguntas tem grande impacto sobre as taxas de identificação partidária reportadas nas pesquisas de opinião (Blaise et al., 2001) ${ }^{8}$. A perenidade do fenômeno da identificação partidária (a mesma cidadã se identifica com determinado partido durante anos ou décadas) é o elo mais fraco da concepção, porque rigorosamente somente estudos de painel durante esse mesmo período conseguiriam confirmar essas afirmações. A consistência dos dados da identificação partidária e o seu poder explicativo para entender atitudes (opiniões) e comportamentos políticos (votação) são indicadores fortes de que o conceito abstrato tem validade real.

Com esse pano de fundo, convém olhar para as perguntas do ESEB em relação à filiação e a identificação partidária. A Tabela 1 informa sobre as sete perguntas do ESEB 2014 para aferir os dois fenômenos. A primeira pergunta sobre a filiação foi respondida (com sim ou não) por 98,5\% dos entrevistados, sendo que $3 \%$ afirmaram estar filiados a um partido político.

Em relação às questões sobre a identificação partidária cabe dividi-las em três blocos. A primeira pergunta não segue o padrão clássico das pesquisas sobre identificação partidária. Refere-se meramente a uma comparação entre o ideário do partido e o ideário do entrevistado. A princípio, não implica uma identificação. Tampouco solicita que o entrevistado identifique o partido. Chamaremos essa dimensão de proximidade para com um partido.

As três perguntas seguintes seguem aproximadamente o padrão das pesquisas internacionais sobre a identificação partidária. A primeira se refere à existência de identificação com algum partido, a segunda solicita identificar o partido e a terceira afere a profundidade do vínculo. Porém, há diferenças importantes em relação a outras pesquisas seguindo o mesmo padrão. Primeiro, a pergunta não fala de identificação partidária, mas usa o verbo gostar. Segundo, a pergunta não verbaliza a intenção de aferir o caráter perene dessa relação, separando a identificação de atitudes mais circunstanciais ${ }^{9}$.

Finalmente, o questionário inclui uma pergunta solicitando ao entrevistado que classifique seu grau de afinidade com relação a cada um dos 12 maiores partidos brasileiros. A pergunta novamente usa o termo gostar para operacionalizar a identificação partidária. Uma vez que as perguntas enfatizam a dimensão afetiva, usaremos essas perguntas para avaliar a empatia com partidos políticos.

Após essas considerações introdutórias podemos analisar o padrão de filiação e identificação partidária na sociedade. Tanto para a filiação como para a identificação partidária usamos apenas a informação genérica, sem levar em conta a qual sigla partidária os entrevistados se referem. O Quadro 1, a seguir, ilustra a distribuição da amostra sobre essas três dimensões de proximidade com o partido. As diferentes dimensões são representadas por um diagrama de Venn, onde as sobreposições parciais representam as combinações entre as várias formas de aproximação aos partidos. As proporções dos círculos e das respectivas intersecções são meramente ilustrativas. As proporções são indicadas na legenda ao lado do gráfico. A primeira coluna identifica a proporção de cada segmento em relação a total dos entrevistados. Verificamos que 62,8\% dos entrevistados (grupo 1) não participam de nenhum círculo de aproximação aos partidos e 1,8\% (grupo 8) participa de todos os círculos. A segunda coluna indica a porcentagem de cada segmento em relação ao grupo de entrevistados que faz parte de pelo menos um círculo de aproximação. Aqui verificamos que há uma grande sobreposição entre a proximidade e a empatia, representando mais da metade da amostra $(61,4 \%$, somando grupo 4 e grupo 8$)$. Na terceira coluna é 
Tabela 1 - Perguntas do ESEB 2014 relacionadas com a filiação e identificação partidária

\begin{tabular}{|c|c|c|c|c|c|c|c|}
\hline Tema & Pergunta & \multicolumn{3}{|c|}{ Respostas válidas* } & \multicolumn{3}{|c|}{ Sem resposta válida } \\
\hline \multirow[t]{4}{*}{ Filiação partidária } & Pergunta 1: & & & & & & \\
\hline & $\begin{array}{l}\text { Gostaria de saber se o(a) sr.(a) é filiado a } \\
\text { algum partido político? }\end{array}$ & \multicolumn{3}{|c|}{$\operatorname{Sim} 75(3,0 \%)$} & \multicolumn{3}{|c|}{ Missing $37(1,5 \%)$} \\
\hline & & \multicolumn{3}{|c|}{ Não $2.394(95,5 \%)$} & & & \\
\hline & $\begin{array}{l}\text { Pergunta 2: A qual partido o(a) sr. (a) é } \\
\text { filiado? }\end{array}$ & Identific & $2(96 \%$ & & \multicolumn{3}{|c|}{ Não identificou 3 (4\%) } \\
\hline \multirow{24}{*}{$\begin{array}{l}\text { Identificação parti- } \\
\text { dária (Proximidade e } \\
\text { empatia) }\end{array}$} & Pergunta 3: & & & & & & \\
\hline & Existe algum partido político que repre- & \multicolumn{3}{|c|}{$\operatorname{Sim} 656(26,2 \%)$} & \multicolumn{3}{|c|}{ Missing $171(6,8 \%)$} \\
\hline & senta a maneira como o(a) sr. (a) pensa & \multicolumn{3}{|c|}{ Não $1.679(67,0 \%)$} & & & \\
\hline & Pergunta 4: & \multicolumn{3}{|c|}{$\operatorname{Sim} 823(32,8 \%)$} & \multicolumn{3}{|c|}{ Missing $35(3,8 \%)$} \\
\hline & $\begin{array}{l}\text { Existe algum partido político que o(a) sr. } \\
\text { (a) goste mais que os outros? }\end{array}$ & \multicolumn{3}{|c|}{ Não $1.589(63,4 \%)$} & & & \\
\hline & Pergunta 5: & \multicolumn{3}{|c|}{ Identificou $798(96,6 \%)$} & \multicolumn{3}{|c|}{$\begin{array}{l}\text { Não identificou } 25 \\
(3,4 \%)\end{array}$} \\
\hline & $\begin{array}{l}\text { Qual partido o(a) sr. (a) gosta? } \\
\text { (Espontânea) }\end{array}$ & & & & & & \\
\hline & Pergunta 6: & & & & & & \\
\hline & Com relação a esse partido, o(a) sr. (a) & \multirow{3}{*}{\multicolumn{3}{|c|}{$\begin{array}{l}\text { Muito } 240(30,1 \%) \\
\text { Gosta } 442(55,5 \%) \\
\text { Pouco } 115(14,4 \%)\end{array}$}} & \multicolumn{3}{|c|}{ Não identificou $0(0 \%)$} \\
\hline & diria que gosta muito, gosta ou gosta um & & & & & & \\
\hline & pouco desse partido! & & & & & & \\
\hline & Pergunta 7: & \multicolumn{3}{|c|}{ Atribuiu nota } & \multicolumn{3}{|c|}{ Não atribuiu nota } \\
\hline & Para cada partido citado, gostaria que & PT & 2176 & $86,8 \%$ & PT & 330 & $13 \%$ \\
\hline & atribuísse uma nota de 0 a 10 , sendo que & PMDB & 1991 & $79,4 \%$ & PMDB & 516 & $21 \%$ \\
\hline & de jeito nenhum do partido e 10 que o(a) & PSDB & 1955 & $78,0 \%$ & PSDB & 551 & $22 \%$ \\
\hline & sr. (a) gosta muito: < partido $>$. & PV & 1656 & $66,1 \%$ & PV & 851 & $34 \%$ \\
\hline & & PDT & 1632 & $65,1 \%$ & PDT & 875 & $35 \%$ \\
\hline & & PSOL & 1615 & $64,4 \%$ & PSOL & 891 & $36 \%$ \\
\hline & & РTB & 1565 & $62,4 \%$ & РTB & 942 & $38 \%$ \\
\hline & & PSB & 1543 & $61,5 \%$ & PSB & 964 & $38 \%$ \\
\hline & & DEM & 1413 & $56,4 \%$ & DEM & 1094 & $44 \%$ \\
\hline & & PSD & 1403 & $56,0 \%$ & PSD & 1104 & $44 \%$ \\
\hline & & PSC & 1358 & $54,2 \%$ & PSC & 1149 & $46 \%$ \\
\hline & & PR & 1328 & $53,0 \%$ & PR & 1178 & $47 \%$ \\
\hline
\end{tabular}

Nota: * No campo das respostas válidas constam (a) o conteúdo da resposta, (b) o número de casos (ponderados) e (c) a porcentagem sobre o total.

Fonte: Os autores, a partir do questionário do ESEB 2014.

possível identificar a distribuição dos segmentos somente entre os entrevistados filiados a algum partido. Novamente o grupo com atributos consistentes (filiados que estão próximos de um partido e tem empatia com um partido) é o maior, com $60,2 \%$. Os filiados com atributos contraditórios quanto à proximidade $\mathrm{e}$ empatia representam 39,8\%. Voltaremos a essa questão mais adiante.

O próximo passo é analisar o perfil dos filiados, dos que se sentem próximos e dos que tem empatia por um partido, separando diferentes segmentos da sociedade. A Tabela 2 identifica na primeira linha novamente as taxas de 
Quadro 1 - Filiação, proximidade e empatia com partidos

${ }^{10}$ Pequenas divergências das somas entre o quadro 01 e a Tabela 2 se devem ao maior número de missing values no primeiro.

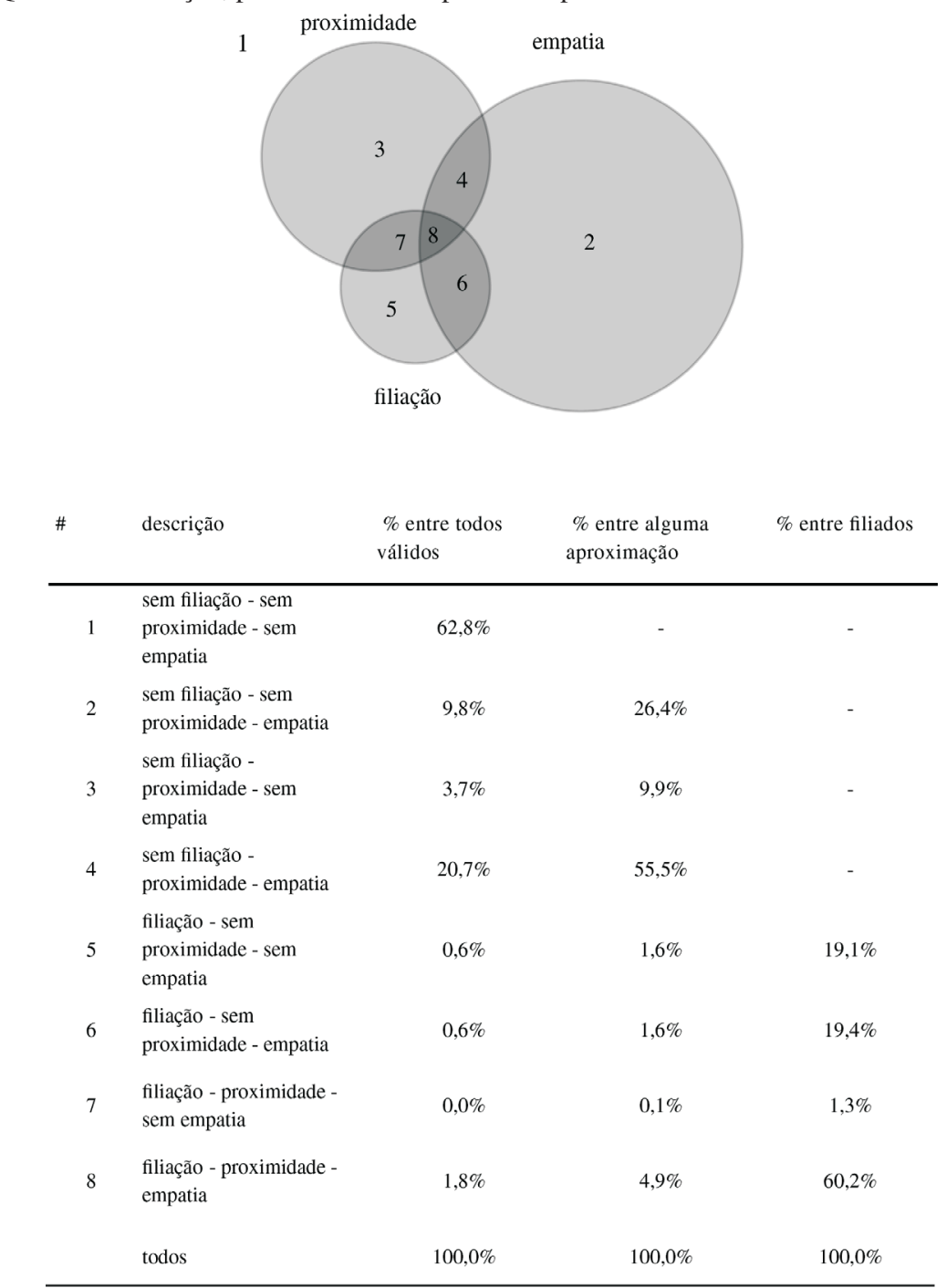

\begin{tabular}{clccc} 
\# & descrição & $\begin{array}{c}\text { \% entre todos } \\
\text { válidos }\end{array}$ & $\begin{array}{c}\text { \% entre alguma } \\
\text { aproximação }\end{array}$ & \% entre filiados \\
\hline 1 & $\begin{array}{l}\text { sem filiação - sem } \\
\text { proximidade - sem } \\
\text { empatia }\end{array}$ & $62,8 \%$ & - & - \\
2 & $\begin{array}{l}\text { sem filiação - sem } \\
\text { proximidade - empatia }\end{array}$ & $9,8 \%$ & $26,4 \%$ & - \\
3 & $\begin{array}{l}\text { sem filiação - } \\
\text { proximidade - sem } \\
\text { empatia }\end{array}$ & $3,7 \%$ & $9,9 \%$ & - \\
4 & $\begin{array}{l}\text { sem filiação - } \\
\text { proximidade - empatia }\end{array}$ & $20,7 \%$ & $55,5 \%$ & - \\
5 & $\begin{array}{l}\text { filiação - sem } \\
\text { proximidade - sem } \\
\text { empatia } \\
\text { filiação - sem } \\
\text { proximidade - empatia }\end{array}$ & $0,6 \%$ & $1,6 \%$ & $19,1 \%$ \\
7 & $\begin{array}{l}\text { filiação - proximidade - } \\
\text { sem empatia }\end{array}$ & $0,6 \%$ & $1,6 \%$ & $19,4 \%$ \\
8 & $\begin{array}{l}\text { filiação - proximidade - } \\
\text { empatia }\end{array}$ & $1,8 \%$ & $1,3 \%$ \\
\hline
\end{tabular}

Fonte: Os autores, a partir do questionário do ESEB 2014.

filiação, de proximidade e de empatia para com os partidos políticos em diferentes segmentos da sociedade. Aqui encontramos novamente as proporções do quadro anterior. Os filiados (grupos 5 a 8) representam 3\% da amostra, os que identificam proximidade com um partido (grupos 3, 4, 7 e 8) são $28,1 \%$ e os que têm empatia com um partido (grupos $2,4,6$, e 8 ) somam $34,1 \% .^{10}$

A Tabela 2 permite comparar esses valores médios de filiação, proximidade e empatia com partidos com os valores médios de subsegmentos da sociedade. Ela é composta a partir de tabelas de contingência bivariadas para cada uma das clivagens analisadas. Reproduzimos somente a parte das tabelas indicando a porcentagem de filiação, proximidade e empatia em cada grupo. Por exemplo, enquanto a taxa de filiação partidária é de $3 \%$ na amostra total, quando separamos a análise por região essa taxa é maior no Norte $(5,1 \%)$ e menor no Sudeste $(1,8 \%)$. Os blocos de linhas informam cada subgrupo e os seus componentes.

Nos primeiros dois critérios, que se referem à distribuição espacial (região e capital), verificamos padrões mais baixos de filiação, proximidade e empatia em relação aos partidos nas regiões Sudeste e Centro-Oeste e padrões mais altos 
Tabela 2 - Perfil da filiação, proximidade e empatia com partidos

\begin{tabular}{|c|c|c|c|c|c|c|c|}
\hline & Filiação & $\begin{array}{c}\text { Resíduo } \\
\text { ajust. estand. }\end{array}$ & $\begin{array}{c}\text { Identificação } \\
\text { por } \\
\text { proximidade }\end{array}$ & $\begin{array}{c}\text { Resíduo } \\
\text { ajust. estand. }\end{array}$ & $\begin{array}{c}\text { Identificação } \\
\text { por empatia }\end{array}$ & $\begin{array}{c}\text { Resíduo } \\
\text { ajust. estand. }\end{array}$ & PCT total \\
\hline Total & $3,0 \%$ & & $28,1 \%$ & & $34,1 \%$ & & $100,0 \%$ \\
\hline \multicolumn{8}{|l|}{ Regiao } \\
\hline Norte & $5,1 \%$ & 1,8 & $28,5 \%$ & 0,1 & $36,5 \%$ & 0,7 & $7,8 \%$ \\
\hline Nordeste & $3,1 \%$ & 0,1 & $34,9 \%$ & 4,4 & $45,6 \%$ & 7,0 & $25,7 \%$ \\
\hline Sudeste & $1,8 \%$ & $-3,1$ & $25,7 \%$ & $-2,3$ & $28,8 \%$ & $-4,9$ & $44,2 \%$ \\
\hline Sul & $6,5 \%$ & 4,1 & $26,4 \%$ & $-0,7$ & $32,7 \%$ & $-0,6$ & $14,5 \%$ \\
\hline Centro - Oeste & $1,1 \%$ & $-1,6$ & $21,3 \%$ & $-2,1$ & $26,5 \%$ & $-2,3$ & $7,8 \%$ \\
\hline \multicolumn{8}{|l|}{ Capital } \\
\hline Interior & $3,6 \%$ & 3,1 & $29,9 \%$ & 3,3 & $36,6 \%$ & 4,4 & $73,7 \%$ \\
\hline Capital & $1,2 \%$ & $-3,1$ & $23,1 \%$ & $-3,3$ & $27,0 \%$ & $-4,4$ & $26,3 \%$ \\
\hline \multicolumn{8}{|l|}{ Mulher } \\
\hline Homem & $4,5 \%$ & 4,1 & $31,5 \%$ & 3,6 & $38,3 \%$ & 4,2 & $48,2 \%$ \\
\hline Mulher & $1,7 \%$ & $-4,1$ & $24,9 \%$ & $-3,6$ & $30,2 \%$ & $-4,2$ & $51,8 \%$ \\
\hline \multicolumn{8}{|l|}{ Faixa idade } \\
\hline 16 a 25 anos & $1,1 \%$ & $-2,8$ & $28,3 \%$ & 0,1 & $32,1 \%$ & $-1,1$ & $19,4 \%$ \\
\hline 26 a 40 anos & $3,5 \%$ & 0,9 & $27,9 \%$ & $-0,1$ & $33,4 \%$ & $-0,6$ & $33,6 \%$ \\
\hline 41 a 64 anos & $3,7 \%$ & 1,6 & $28,5 \%$ & 0,3 & $35,1 \%$ & 0,8 & $36,7 \%$ \\
\hline 65 anos ou mais & $2,7 \%$ & $-0,3$ & $26,9 \%$ & $-0,4$ & $36,9 \%$ & 1,0 & $10,3 \%$ \\
\hline \multicolumn{8}{|l|}{ Cor } \\
\hline Preto & $1,4 \%$ & $-1,7$ & $30,4 \%$ & 0,9 & $36,3 \%$ & 0,9 & $11,6 \%$ \\
\hline Pardo & $2,7 \%$ & $-0,7$ & $29,0 \%$ & 0,9 & $35,0 \%$ & 0,9 & $46,5 \%$ \\
\hline Branco & $3,9 \%$ & 2,2 & $26,6 \%$ & $-1,3$ & $32,1 \%$ & $-1,6$ & $39,5 \%$ \\
\hline Amarelo & $0,0 \%$ & $-1,1$ & $24,3 \%$ & $-0,5$ & $37,8 \%$ & 0,5 & $1,5 \%$ \\
\hline Índio & $0,0 \%$ & $-0,8$ & $23,5 \%$ & $-0,4$ & $36,8 \%$ & 0,3 & $0,8 \%$ \\
\hline \multicolumn{8}{|l|}{ Escolaridade completada } \\
\hline Analf & $2,5 \%$ & $-0,5$ & $26,3 \%$ & $-0,7$ & $38,7 \%$ & 1,7 & $11,0 \%$ \\
\hline Pri. grau & $2,3 \%$ & $-1,2$ & $26,5 \%$ & $-1,0$ & $33,7 \%$ & $-0,2$ & $24,2 \%$ \\
\hline Seg. grau & $2,4 \%$ & $-0,9$ & $29,5 \%$ & 0,7 & $32,6 \%$ & $-0,8$ & $20,0 \%$ \\
\hline Coleg & $3,1 \%$ & 0,2 & $27,7 \%$ & $-0,3$ & $33,0 \%$ & $-0,8$ & $35,5 \%$ \\
\hline Univ & $6,6 \%$ & 3,3 & $33,0 \%$ & 1,7 & $36,8 \%$ & 0,9 & $9,2 \%$ \\
\hline \multicolumn{8}{|l|}{ Estado civil } \\
\hline Casada/o & $2,9 \%$ & $-0,3$ & $29,3 \%$ & 1,7 & $34,9 \%$ & 1,0 & $62,2 \%$ \\
\hline Solteira/o & $3,1 \%$ & 0,1 & $26,6 \%$ & $-1,0$ & $32,4 \%$ & $-1,1$ & $26,8 \%$ \\
\hline Separada/o & $4,1 \%$ & 0,8 & $23,5 \%$ & $-1,2$ & $35,2 \%$ & 0,3 & $5,9 \%$ \\
\hline Viúva/o & $2,4 \%$ & $-0,4$ & $26,3 \%$ & $-0,5$ & $32,8 \%$ & $-0,3$ & $5,1 \%$ \\
\hline \multicolumn{8}{|l|}{ Religiao } \\
\hline Catolico & $3,2 \%$ & 1,0 & $28,2 \%$ & 0,2 & $34,8 \%$ & 1,0 & $62,9 \%$ \\
\hline Evangelico & $2,2 \%$ & $-1,2$ & $30,0 \%$ & 1,1 & $32,8 \%$ & $-0,7$ & $23,6 \%$ \\
\hline Outras & $1,0 \%$ & $-1,7$ & $22,6 \%$ & $-1,7$ & $30,3 \%$ & $-1,2$ & $8,1 \%$ \\
\hline S/religiao & $6,3 \%$ & 2,2 & $26,2 \%$ & $-0,5$ & $36,2 \%$ & 0,5 & $5,4 \%$ \\
\hline \multicolumn{8}{|l|}{ Renda faixa } \\
\hline Até $1 \mathrm{SM}$ & $1,5 \%$ & $-1,8$ & $28,7 \%$ & $-0,2$ & $43,9 \%$ & 3,2 & $12,3 \%$ \\
\hline De 1 A 2 SM & $2,7 \%$ & $-1,1$ & $25,4 \%$ & $-2,3$ & $28,9 \%$ & $-3,7$ & $27,4 \%$ \\
\hline De 2 A 5 SM & $3,6 \%$ & 0,5 & $29,1 \%$ & 0,0 & $34,9 \%$ & $-0,2$ & $45,5 \%$ \\
\hline Acima $5 \mathrm{SM}$ & $5,6 \%$ & 2,4 & $36,4 \%$ & 3,0 & $40,3 \%$ & 2,0 & $14,8 \%$ \\
\hline \multicolumn{8}{|l|}{ Classe subjetiva } \\
\hline Desceu & $4,9 \%$ & 1,2 & $29,0 \%$ & $-0,0$ & $32,4 \%$ & $-0,7$ & $6,1 \%$ \\
\hline Estagnou & $2,4 \%$ & $-2,9$ & $23,4 \%$ & $-7,8$ & $28,4 \%$ & $-8,9$ & $63,5 \%$ \\
\hline Subiu & $4,5 \%$ & 2,4 & $41,1 \%$ & 8,2 & $49,8 \%$ & $\mathbf{9 , 7}$ & $30,4 \%$ \\
\hline \multicolumn{8}{|l|}{ Bolsa familia } \\
\hline Não & $3,5 \%$ & 2,0 & $26,9 \%$ & $-2,0$ & $32,9 \%$ & $-2,2$ & $70,5 \%$ \\
\hline $\mathrm{Sim}$ & $1,9 \%$ & $-2,0$ & $30,9 \%$ & 2,0 & $37,6 \%$ & 2,2 & $29,5 \%$ \\
\hline
\end{tabular}

Fonte: Os autores, a partir do questionário do ESEB 2014. 
11 Para avaliar se a diferença entre a média geral e a média dos subsegmentos é significativa, usamos o indicador do resíduo ajustado estandardizado. Ele é uma medida mais sofisticada calculada a partir do qui-quadrado, que mede a correlação entre duas variáveis categóricas em tabelas de contingência, permitindo identificar se as diferenças são estatisticamente significativas. Um resíduo com valor absoluto acima de 2 indica que há somente $5 \%$ de chance que esse desvio da média seja espúrio (não existe na população).

12 O conceito de "cidadão crítico" ou "democrata insatisfeito" se refere aos eleitores mais sofisticados politicamente e que, portanto, apoiam de forma clara os valores gerais da democracia, mas estão fortemente insatisfeitos com o funcionamento dos regimes representativos realmente existentes. no Nordeste. As taxas de filiação, proximidade e empatia com partidos no Sudeste estão significativamente abaixo da média nacional ${ }^{11}$. Uma hipótese para explicar esse aparente paradoxo, a ser explorada futuramente, pode estar na emergência do que os autores em Norris (1999) denominaram de "cidadão crítico" $"$. No Centro-Oeste temos resultados parecidos para a identificação partidária abaixo da média e no Nordeste é possível identificar um padrão acima da média nacional.

Também há uma grande diferença entre capitais e interior. Em todas as três dimensões - filiação, proximidade e empatia com os partidos - os entrevistados do interior apresentam maior proximidade com os partidos do que os habitantes das capitais. Isso parece indicar que a proximidade interpessoal (mais intensa nas cidades menores) tem um peso significativo na filiação a partidos. Essa hipótese encontra confirmação nos resultados do estudo de Speck (2013) sobre filiação a partidos entre os municípios brasileiros: nos municípios até 5 mil habitantes a taxa de filiação média é de $24 \%$. No outro extremo, entre os municípios acima de 200 mil habitantes, a taxa, inferior à média nacional $(10,7 \%)$, é de $8 \%$.

Passando para as características individuais dos entrevistados, verificamos que na questão de gênero a sociedade é dividida. As mulheres são significativamente menos filiadas, se sentem menos próximas e manifestam menos empatia com as organizações partidárias. Outras características, como estado civil e religião influenciam a filiação e a identificação partidária enquanto a idade, a cor e a escolaridade influenciam, de forma significativa, somente a filiação partidária.

A condição socioeconômica, tipicamente um determinante importante para os padrões de comportamento político, não influencia significativamente a proximidade dos cidadãos com os partidos quando levamos em conta a classificação por faixa de renda. Somente os cidadãos da classe A e B (acima de cinco salários mínimos) apresentam padrões de proximidade e empatia maior com os partidos políticos. Por outro lado, a mudança de status social, avaliada a partir da percepção dos próprios entrevistados deixa marcas claras na relação com os partidos. Os cidadãos que avaliam que sua posição na sociedade não mudou se engajam menos nos partidos, estão menos próximos a esses e tem menos empatia do que os cidadãos em ascensão social. Essa constatação é relevante porque ela indica que a mobilidade social politiza as pessoas e as leva a se engajar no sistema político. Uma constatação bem diferente da suspeita que a ascensão econômica levasse à alienação da política e à retração para a vida privada. Outra forma de avaliar a condição socioeconômica se refere à inclusão da família no programa bolsa família. Na última coluna identificamos que $29,5 \%$ dos entrevistados se encontram nessa condição. Os resultados quanto à aproximação aos partidos indicam que os beneficiários do programa bolsa família se encontram mais longe dos partidos políticos em todas as dimensões. Apresentam menor taxa de filiação, estão menos próximos e tem menos empatia com os partidos. Todos os resultados em relação ao critério bolsa família são estatisticamente significativos.

É importante lembrar que essas análises bivariadas são apenas uma primeira avaliação dos fatores que influenciam a proximidade entre cidadãos e partidos políticos. Elas devem ser complementadas por análises mais sofisticadas que seguem mais adiante nesse texto.

\section{A comparação entre filiação, proximidade e empatia com partidos}

Como é a relação entre a proximidade e a empatia por partidos? Cidadãos que declaram gostar de determinado partido tem de fato menos empatia com os 
outros partidos? Essa relação fica mais clara na medida em que é mais intensa? Há congruência entre as diferentes manifestações a respeito da proximidade e empatia com partidos? Os cidadãos que se declaram próximos a um partido também têm maior empatia com esse partido? E, finalmente, qual é a conexão entre a filiação partidária, a proximidade com partidos e a empatia por partidos?

Nessa segunda etapa avaliamos a consistência interna das diferentes medidas para aferir a identificação partidária, bem como a congruência entre identificação e filiação partidária. A diferença entre os dois conceitos é que contradições fortes entre as diferentes manifestações da identificação racional e emocional colocam em dúvida a utilidade do conceito no sentido em que ele foi concebido pelos cientistas políticos. A estabilidade, profundidade e abrangência dos vínculos de identificação são elementos centrais para usar o conceito como variável latente que influencia outros fatores contextuais. No que diz respeito à questão da relação entre identificação partidária e filiação partidária preferimos falar de congruência. Aqui queremos justamente avaliar o significado da filiação partidária a partir da comparação com diferentes dimensões de identificação com os partidos.

\section{III.1. Consistência da empatia por partidos}

${ }^{13} \mathrm{Na}$ verdade, são avaliados apenas 12 partidos (PT, PMDB, PSDB, PDRT, DEM, PV, PTB, PSB, PR, PSOL, PSC e PSB), representando 374 cadeiras ( $73 \%$ das 513$)$ na Câmara dos Deputados, em 2014.
A primeira avaliação se refere à consistência interna da empatia por determinado partido político. Comparamos primeiramente as respostas à pergunta cinco com as da pergunta sete. Na primeira, o entrevistado deve identificar o partido que gosta mais e na pergunta sete ele deve dar uma nota para cada um de 12 partidos identificando o quanto gosta de cada um deles. Se a empatia para com determinado partido for consistente, as duas respostas deveriam indicar o mesmo partido como mais preferido. Comparamos as respostas às duas perguntas, classificando a identificação partidária como consistente quando o entrevistado que identificou (na pergunta cinco) o partido A como aquele que mais gosta também deu a nota mais alta a esse partido na avaliação de todos os partidos (na pergunta sete) ${ }^{13}$. Quando um dos outros partidos foi melhor avaliado que o partido indicado na questão cinco, classificamos a resposta como contraditória.

O resultado da comparação está na Tabela 3, a seguir, onde percebemos (na última linha) que três entre quatro entrevistados $(75,3 \%)$ que identificam um dos doze partidos avaliados na pergunta 7 como partido preferido também avaliam esse partido como o mais alto na escala de preferências comparativas (pergunta 5). Quando analisamos as respostas separadamente por intensidade de empatia essa taxa é significativamente mais baixa para os que gostam pouco do partido $(58,2 \%)$ e mais alta para os que gostam muito do partido $(83,3)^{14}$. Isso indica que os dados sobre a empatia com partidos são consistentes para a maioria dos cidadãos que se identificam com um dos partidos. Por outro lado, o grupo de cidadãos com empatia aparentemente contraditória é grande e merecerá atenção especial.

\section{III.2. Comparando a proximidade com a empatia por partidos}

14 Na tabela usamos novamente os resíduos ajustados para testar se a diferença entre as porcentagens nos três grupos é espúria ou estatisticamente significativa. Valores acima ou abaixo de 2 nos resíduos ajustados indicam uma probabilidade de $5 \%$ de erro
A segunda avaliação da consistência da identificação partidária se refere à comparação entre a dimensão racional (proximidade de ideias) e a dimensão afetiva (gostar de um partido).

A Tabela 4 mostras que 27,9\% dos entrevistados identificam proximidade com um dos partidos político. No total $(2,5+13,2+8,4), 24,1 \%$ estão em ambas as categorias. No outro extremo estão $62,4 \%$ dos entrevistados que não tem nenhum vínculo nem racional, nem afetivo com um partido. Analisando os resultados por grau de intensidade da empatia verificamos diferenças signifi- 


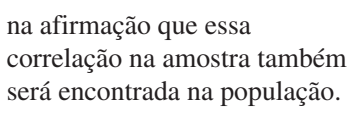

Tabela 3 - Consistência entre diferentes indicadores de empatia com partidos

\begin{tabular}{|c|c|c|c|c|}
\hline & & \multicolumn{3}{|c|}{$\begin{array}{c}\text { Avaliação individual dos partidos } \\
\text { segundo empatia }\end{array}$} \\
\hline & & Contraditória & Consistente & Total \\
\hline \multirow[t]{4}{*}{ Gosta muito } & Valor encontrado & 19 & 95 & 114 \\
\hline & Valor esperado & 28 & 86 & 114 \\
\hline & $\%$ do Total & $4,9 \%$ & $24,5 \%$ & $29,4 \%$ \\
\hline & Resíduo ajustado & $-2,4$ & 2,4 & \\
\hline \multirow[t]{4}{*}{ Gosta } & Valor encontrado & 54 & 165 & 219 \\
\hline & Valor esperado & 54 & 165 & 219 \\
\hline & $\%$ do Total & $13,9 \%$ & $42,5 \%$ & $56,4 \%$ \\
\hline & Resíduo ajustado &, 0 &, 0 & \\
\hline \multirow[t]{4}{*}{ Gosta um pouco } & Valor encontrado & 23 & 32 & 55 \\
\hline & Valor esperado & 14 & 41 & 55 \\
\hline & $\%$ do Total & $5,9 \%$ & $8,2 \%$ & $14,2 \%$ \\
\hline & Resíduo ajustado & 3,2 & $-3,2$ & \\
\hline \multirow[t]{3}{*}{ Total } & Valor encontrado & 96 & 292 & 388 \\
\hline & Valor esperado & 96 & 292 & 388 \\
\hline & $\%$ do Total & $24,7 \%$ & $75,3 \%$ & $100,0 \%$ \\
\hline
\end{tabular}

Fonte: Os autores, a partir do questionário do ESEB 2014.

cativas em relação à correlação entre as duas variáveis. Quanto mais forte a empatia, maior a probabilidade de também estar no grupo dos cidadãos que percebe proximidade com o programa de um dos partidos.

\section{III.3. A filiação e a identificação partidária}

Tendo validado o conceito da identificação partidária a partir da comparação entre várias perguntas do ESEB 2014, resta, finalmente, avaliar a relação entre a identificação, de um lado, e a filiação partidária, do outro. Entre os filiados, qual a presença de cidadãos emocionalmente e/ou racionalmente mais próximos aos partidos? Avaliamos essa relação em dois passos. Primeiro, comparamos a filiação com a intensidade da empatia partidária. Depois, usamos testes mais exigentes para avaliar a consistência entre identificação e filiação partidária.

$\mathrm{Na}$ Tabela 5 podemos identificar o grau de congruência entre filiação e identificação partidária. Verificamos, em primeiro lugar, que quatro entre cinco filiados informam gostar de um dos partidos políticos, uma taxa de consistência que talvez esteja distante do que o sendo comum sobre o perfil dos filiados indica.

O ESEB 2014 oferece possibilidade de testes mais exigentes sobre a congruência entre filiação e identificação partidária. Para os que responderam afirmativamente às duas perguntas (2,5\% da amostra) a informação solicitada em sequência era sobre a sigla partidária da filiação ou identificação. A surpresa na comparação desse grupo de filiados que gostam de um partido é que um entre três entrevistados informou siglas diferentes na resposta às duas perguntas. Essa incongruência não invalida nenhuma das duas informações, mas deixa questões sobre o significado da filiação partidária no caso brasileiro. Na Tabela 6 
Tabela 4 - Consistência entre empatia e proximidade com partidos

\begin{tabular}{|c|c|c|c|c|}
\hline & & \multicolumn{3}{|c|}{ Um partido representa como entrevistado pensa* } \\
\hline & & Não & Sim & Total \\
\hline \multirow[t]{4}{*}{ Não gosta de nenhum } & Valor encontrado & 1.418 & 88 & 1.506 \\
\hline & Valor esperado & 1.086 & 420 & 1.506 \\
\hline & $\%$ do Total & $62,4 \%$ & $3,9 \%$ & $66,3 \%$ \\
\hline & Resíduo ajustado & 32,9 & $-32,9$ & \\
\hline \multirow[t]{4}{*}{ Gosta um pouco } & Valor encontrado & 50 & 56 & 106 \\
\hline & Valor esperado & 76 & 30 & 106 \\
\hline & $\%$ do Total & $2,2 \%$ & $2,5 \%$ & $4,7 \%$ \\
\hline & Resíduo ajustado & $-5,9$ & 5,9 & \\
\hline \multirow[t]{4}{*}{ Gosta } & Valor encontrado & 127 & 299 & 426 \\
\hline & Valor esperado & 307 & 119 & 426 \\
\hline & $\%$ do Total & $5,6 \%$ & $13,2 \%$ & $18,8 \%$ \\
\hline & Resíduo ajustado & $-21,6$ & 21,6 & \\
\hline \multirow[t]{4}{*}{ Gosta muito } & Valor encontrado & 42 & 191 & 233 \\
\hline & Valor esperado & 168 & 65 & 233 \\
\hline & $\%$ do Total & $1,8 \%$ & $8,4 \%$ & $10,3 \%$ \\
\hline & Resíduo ajustado & $-19,4$ & 19,4 & \\
\hline \multirow[t]{3}{*}{ Total } & Valor encontrado & 1.637 & 634 & 2.271 \\
\hline & Valor esperado & 1.637 & 634 & 2.271 \\
\hline & $\%$ do Total & $72,1 \%$ & $27,9 \%$ & $100,0 \%$ \\
\hline
\end{tabular}

Nota: * O questionário não inclui pergunta identificando esse partido.

Fonte: Os autores, a partir do questionário do ESEB 2014.

resumimos as informações sobre o perfil dos filiados à luz dessa comparação com a identificação partidária.

O grupo dos filiados com identificação partidária congruente abrange aproximadamente metade $(50,2)$ dos filiados. Entretanto, temos dois grupos entre os filiados que despertam curiosidade. Por um lado, um entre cada cinco respondentes $(21,3 \%)$ que se diz filiado não guarda nenhum tipo de relação afetiva com o partido e outro grupo maior $(28,5 \%)$ dirige sua empatia a outro partido. Certamente, esse resultado não implica voltar à estaca anterior e considerar a filiação partidária um fenômeno desprovido de conteúdo. Mas, também, não permite que leiamos qualquer filiação como expressão de um compromisso mais intenso com determinado partido. Antes, esses resultados, aparentemente contraditórios, sugerem que futuras pesquisas terão de levar em conta esses diversos comportamentos em relação aos tipos de vínculos entre eleitores e partidos e buscarem explicações para esses diferentes padrões. Nas conclusões procuramos levantar algumas hipóteses complementares que possam explicar essa aparente contradição.

III.4. Filiação e identificação partidária nos partidos de esquerda, centro e direita

Ao traçar o perfil dos filiados e simpatizantes dos partidos brasileiros, na primeira parte, e avaliar a consistência interna dos conceitos de filiação e identificação, na segunda, verificamos que estamos lidando com conceitos de significado substancial, tendo em vista que as análises sobre organizações partidárias e processos eleitorais no Brasil deram pouco destaque a esses dois 
Tabela 5 - Filiação partidária e intensidade da empatia por partidos

\begin{tabular}{|c|c|c|c|c|}
\hline & & \multicolumn{3}{|c|}{ Entrevistado está filiado a um partido } \\
\hline & & Não & Sim & Total \\
\hline \multirow[t]{4}{*}{ Não gosta de nenhum } & Valor encontrado & 1.552 & 15 & 1.567 \\
\hline & Valor esperado & 1.518 & 49 & 1.567 \\
\hline & $\%$ do Total & $65,9 \%$ & $0,6 \%$ & $66,5 \%$ \\
\hline & Resíduo ajustado & 8,5 & $-8,5$ & \\
\hline \multirow[t]{4}{*}{ Gosta um pouco } & Valor encontrado & 107 & 7 & 114 \\
\hline & Valor esperado & 110 & 4 & 114 \\
\hline & $\%$ do Total & $4,5 \%$ & $0,3 \%$ & $4,8 \%$ \\
\hline & Resíduo ajustado & $-1,9$ & 1,9 & \\
\hline \multirow[t]{4}{*}{ Gosta } & Valor encontrado & 409 & 27 & 436 \\
\hline & Valor esperado & 422 & 14 & 436 \\
\hline & $\%$ do Total & $17,4 \%$ & $1,1 \%$ & $18,5 \%$ \\
\hline & Resíduo ajustado & $-4,1$ & 4,1 & \\
\hline \multirow[t]{4}{*}{ Gosta muito } & Valor encontrado & 214 & 24 & 238 \\
\hline & Valor esperado & 231 & 7 & 238 \\
\hline & $\%$ do Total & $9,1 \%$ & $1,0 \%$ & $10,1 \%$ \\
\hline & Resíduo ajustado & $-6,6$ & 6,6 & \\
\hline \multirow[t]{3}{*}{ Total } & Valor encontrado & 2.282 & 73 & 2.355 \\
\hline & Valor esperado & 2.282 & 73 & 2.355 \\
\hline & $\%$ do Total & $96,9 \%$ & $3,1 \%$ & $100,0 \%$ \\
\hline
\end{tabular}

Fonte: Os autores, a partir do questionário do ESEB 2014.

${ }^{15}$ Na nossa classificação o grupo dos partidos de esquerda é formado por PCB, PCO, PC do B, PDT, PPS,PSB, PSOL, PSTU,PT e PV; os de centro são PMDB e PSDB e os de direita são DEM, PEN, PHS, PMN, PP, PPL, PR, PRB, PRP, PRTB, PSC, PSD, PSDC, PSL, PTB, PTC, PTN, PROS e SD. fenômenos. A suposição corrente é que a filiação seja um fenômeno formal, desprovido de significado relevante para os próprios filiados. Da mesma forma, a identificação partidária teria um sentido limitado em um país onde muitas organizações partidárias foram criadas há pouco tempo.

Esta seção aplica os resultados da análise anterior ao espectro dos partidos políticos. Para esse fim agrupamos os partidos conforme a sua orientação ideológica em esquerda, centro e direita (Tabela 7) ${ }^{15}$.

A Tabela 7 mostra, em primeiro lugar, como a identificação e a filiação partidária estão distribuídas entre os três grupos de partidos de esquerda, centro e direita. Enquanto em relação à empatia os partidos de esquerda ocupam dois terços do espectro $(64,9 \%)$, os partidos de centro representam um terço $(30,9 \%)$ e os de direita ocupam um lugar marginal (4,2\%). Em relação aos filiados a distribuição é mais equilibrada. Aqui dois em cada cinco entrevistados estão

Tabela 6 - Filiação partidária e consistência com a empatia por partidos

\begin{tabular}{lcc}
\hline Situação da filiação & n & pct \\
\hline Filiados que não gostam de nenhum partido & 15 & $21,3 \%$ \\
Filiados que gosta de outro partido & 21 & $28,5 \%$ \\
Filiado gosta do próprio partido & 36 & $50,2 \%$ \\
Total & 72 & $100,0 \%$ \\
\hline
\end{tabular}

Fonte: Os autores, a partir do questionário do ESEB 2014. 
filiados a partidos de esquerda, um a partidos de centro e outros dois a partidos de direita. Essas diferenças na densidade da filiação e da identificação abrem debates interessantes em relação a diferenças de significado dessas aproximações para partidos de esquerda e de direita.

A análise da intensidade da empatia com partidos políticos em diferentes lugares do espectro ideológico confirma que nos partidos de esquerda tende a prevalecer um compromisso mais intenso enquanto nos partidos de centro e direita a identificação tende a ser mais superficial. Na análise das relações contraditórias (identificação de um partido como mais próximo, mas avaliação melhor de outro partido) os partidos de centro e direita igualmente apresentam índices maiores de contradição. Enquanto a taxa média de lealdades conflitantes é de $16 \%$ nos partidos de esquerda, ela sobe para $37 \%$ e $50 \%$ nos partidos de centro e direita, respectivamente.

Em relação à filiação a tendência aponta na mesma direção. A parcela dos filiados a partidos de esquerda que não tem nenhuma relação afetiva com partidos políticos é pequena $(12,9 \%)$, mas ela cresce nos partidos de centro $(21,4 \%)$ e direita $(26,9 \%)$. Devido ao pequeno número de casos esses resultados não são estatisticamente significativos. No outro extremo estão os filiados que gostam muito do partido. Esses representam a metade dos filiados nos partidos de esquerda, mas somente $25 \%$ dos filiados nos partidos de centro e de direita.

Quando analisamos a consistência entre lealdade por empatia e filiação partidária, constatamos uma pequena diferença na incidência de vínculos contraditórios (diz-se filiado a um partido, mas gosta de outro) entre partidos de

Tabela 7 - Dimensões da identificação e filiação partidária no espectro ideológico dos partidos

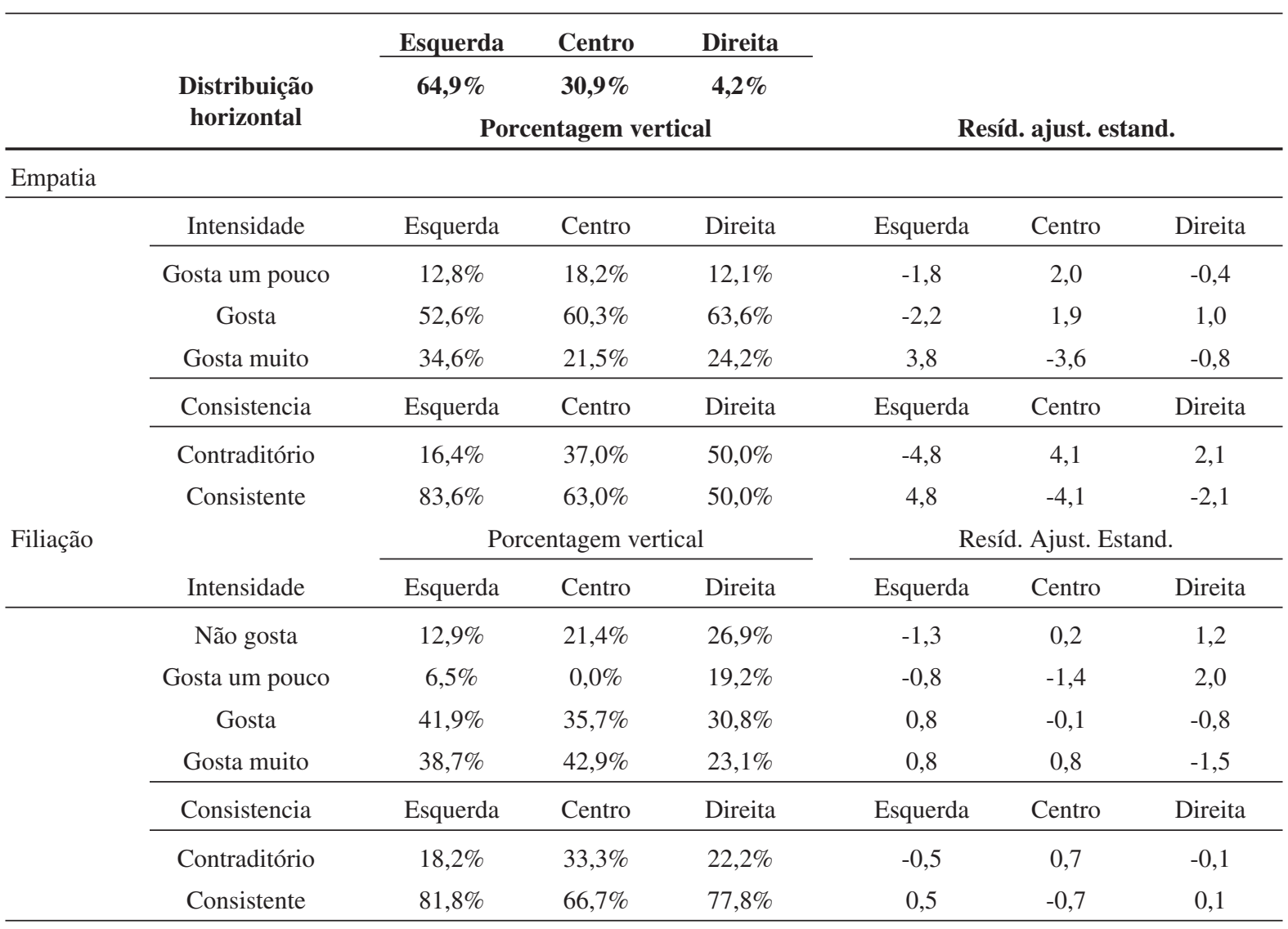

Fonte: Os autores, a partir do questionário do ESEB 2014. 
esquerda e de direita em relação aos partidos de centro. Porém, devido ao baixo número de casos não podemos afirmar que esse quadro se manteria também na população.

III.5. Influência da filiação e identificação partidárias sobre atitudes e comportamentos políticos

${ }^{16}$ As sete modalidades de ativismo político são participar em (a) abaixo assinado, (b) manifestação/protesto, (c) greve, (d) bloqueio de estrada, (e) ocupação de prédio, (f) ocupação de terra e $(\mathrm{g})$ política em redes sociais.
Após a análise descritiva e os diferentes testes de consistência e profundidade dos conceitos da filiação e identificação partidária resta testar o seu poder explicativo sobre o comportamento dos cidadãos. Se a filiação se resume a um ato formal, desprovido de conteúdo ou compromisso com o partido, o comportamento político dos filiados não deveria ser diferente do comportamento dos outros cidadãos não filiados. Da mesma forma, o conceito da identificação partidária tenta captar vários graus de proximidade e empatia com determinados partidos, baseado no argumento de que essas são predisposições veladas que permitem entender diferentes padrões de comportamento e atitudes políticas.

Para verificar a utilidade explicativa dos conceitos de filiação e empatia com partidos identificamos cinco manifestações afetivas de padrões de comportamento os quais acreditamos que deveriam ser influenciados pela filiação e identificação partidária, caso esses conceitos carreguem o significado esperado. Analisamos, primeiramente, um aspecto informacional. Aproximadamente um em cada cinco entrevistados declarou não conhecer a classificação esquerdadireita. Usamos essa informação para criar a primeira variável binária onde 0 significa que o entrevistado não saber usar essas categorias e 1 significa que declarou conhecê-las. A segunda dimensão se refere às diferentes formas de ativismo político dos entrevistados. Esses foram classificados como 1 se informaram ter participado em pelo menos uma das sete modalidades de participação citadas $^{16}$. Três entre cada quatro entrevistados não se engajaram em nenhuma das atividades políticas citadas e foram classificados como 0 . A terceira dimensão de comportamento político se refere ao associativismo político. Os entrevistados que informam ser membros de um sindicato, de uma associação empresarial, de fazendeiros ou informam fazer parte de uma associação profissional são classificados como 1 . Nove entre dez entrevistados não fazem parte de nenhuma organização e foram classificados com 0.

Finalmente, analisamos as informações sobre a votação partidária nos cinco diferentes cargos eleitos no primeiro turno da eleição de 2014, contando o número de vezes que o entrevistado votou em candidatos de um mesmo partido. O número poderia variar de 1 (votou em partidos diferentes para cada um dos cargos) até 5 (votou no mesmo partido para Presidente, Governador, Senador, Deputado Federal e Estadual). Classificamos com 0 os cidadãos que votaram uma ou duas vezes no mesmo cargo. Aproximadamente um em cada quatro entrevistados votaram no mesmo partido entre 3 a 5 cargos e foram classificados com 1, isto é, como aqueles que apresentam um padrão de votação estável.

Classificamos a nossa primeira variável independente, a filiação, de forma binária. O baixo número de casos não permitiu introduzir separações por ideologia ou tipos de filiação, como o item anterior sugeriu. Por outro lado, separamos quatro graus diferentes de empatia com partidos, a partir da pergunta se os entrevistados gostavam pouco, gostavam ou gostavam muito de um partido. Para essas categorias foram criadas variáveis dummy. O grupo dos que não gostavam de nenhum partido é a categoria de referência.

Para controlar por eventuais fatores colaterais incluímos uma série de variáveis de controle referentes à região, à localização (capital), características demográficas e socioeconômicas dos entrevistados. 
Usamos regressão logística multivariada, explicando a ocorrência da filiação, do conhecimento sobre ideologias políticas, do ativismo e associativismo e do padrão de votação. Os resultados dessas análises são resumidos na Tabela 8.

Na primeira análise (coluna 2) explicamos a filiação partidária a partir da identificação partidária. Verificamos que, em comparação com os cidadãos que não gostam de nenhum partido, os que gostam de um partido tem uma chance maior de filiação. Os que "gostam um pouco" têm 4,7 vezes a chance de se filiar, os que "gostam" 5,1 vezes e os que "gostam muito", 9,2.

$\mathrm{Na}$ segunda coluna analisamos o impacto da filiação e da identificação partidária sobre o conhecimento político. A filiação partidária tem influência significativa, aumentando em 2,4 vezes as chances de saber identificar esquerda e direita. A identificação partidária novamente desponta como significativa. Cidadãos que gostam ou que gostam muito de um partido têm 63-85\% mais chances de conhecerem as categorias esquerda-direita do que cidadãos que não gostam de nenhum partido.

Em relação ao ativismo encontramos resultados significativos para todas as categorias da filiação e da identificação partidária, aumentando as chances de se engajar em uma das atividades citadas.

Em relação ao associativismo, os resultados apontam na mesma direção. No primeiro caso há ainda uma clara correlação entre a filiação partidária e outras formas de associativismo. Em relação à identificação partidária há resultados significativos somente para a primeira categoria.

Os resultados a respeito dos padrões de votação em determinado partido confirmam a hipótese da relevância da identificação partidária para entender os padrões de comportamento político. Os filiados a determinado partido têm quase o dobro de probabilidade de votar no mesmo partido para vários cargos em comparação com os não-filiados. Da mesma forma, a empatia mais forte com um partido dobra a propensão de o entrevistado votar de forma mais consistente em determinada sigla partidária.

Também verificamos que algumas variáveis de controle têm forte influência sobre filiação, conhecimento político, ativismo, associativismo e comportamento eleitoral. Região, capital e gênero exercem forte influencia sobre as dimensões de comportamento político analisadas. Outros fatores como cor, educação, religião e classe (tanto objetiva como autoavaliada) têm um peso reduzido para entender as dimensões analisadas. $O$ fato de receber bolsa família aumenta somente o conhecimento político, sem influenciar as outras dimensões do comportamento político.

\section{Conclusões}

Partindo-se de 1980 como o marco inicial do atual sistema partidário, constatamos que os principais partidos políticos estão na disputa política há mais de 35 anos, sendo essa experiência partidária a mais longa de nossa história política. Trata-se, portanto, de tempo suficiente para que esses partidos tenham criado vínculos com segmentos da sociedade, assim como atraído apoio mais ou menos estável entre grupos de cidadãos. De acordo com Pizzorno (1966) os vínculos entre partidos e eleitores necessitam de um tempo político de mais ou menos uma geração e meia (cerca de 30 anos) para atingir razoável consistência.

Foi com o objetivo de avaliar o estado desses vínculos entre eleitores e os partidos mais relevantes do atual sistema partidário que desenvolvemos esse artigo. Para isso, nosso ponto de partida foram duas tradições de pesquisa no campo do comportamento político. A primeira foi a vertente organizacional, 
Tabela 8 - Poder explicativo da filiação e identificação partidária

\begin{tabular}{|c|c|c|c|c|c|}
\hline Variáveis independentes & $\begin{array}{l}\text { Está filiado a } \\
\text { um partido }\end{array}$ & $\begin{array}{c}\text { Sabe identificar } \\
\text { esquerda e } \\
\text { direita }\end{array}$ & $\begin{array}{c}\text { Se engajou } \\
\text { politicamente }\end{array}$ & $\begin{array}{c}\text { Está filiado a } \\
\text { uma } \\
\text { organização }\end{array}$ & $\begin{array}{c}\text { Votou no mesmo } \\
\text { partido para } 3 \\
\text { ou mais cargos }\end{array}$ \\
\hline Filiação a um partido & & $2,42 *$ & $2,60 * * *$ & $2,54 * * *$ & $1,88 * *$ \\
\hline \multicolumn{6}{|l|}{ Gosta de nenhum partido (ref.) } \\
\hline Gosta um pouco de um partido & $4,69 * * *$ & 1,08 & $1,53 *$ & $2,59 * * *$ & 0,89 \\
\hline Gosta de um partido & $5,13 * * *$ & $1,85 * * *$ & $1,47 * * *$ & 1,06 & $2,16 * * *$ \\
\hline Gosta muito de um partido & $9,20 * * *$ & $1,63 * *$ & $2,34 * * *$ & 1,26 & $2,11 * * *$ \\
\hline \multicolumn{6}{|l|}{ Região Sudeste (ref.) } \\
\hline Região Norte & $4,66 * * *$ & 0,78 & $1,51 * *$ & $2,27 * * *$ & $0,19 * * *$ \\
\hline Região Nordeste & $2,19 * *$ & $1,35 *$ & $0,64 * * *$ & $1,57 * *$ & $0,41 * * *$ \\
\hline Região Sul & $3,92 * * *$ & 1,02 & 1,24 & $1,85 * * *$ & 0,85 \\
\hline Região Centro-Oeste & 1,23 & 0,86 & $0,47 * * *$ & 0,82 & $0,29 * * *$ \\
\hline \multicolumn{6}{|l|}{ Interior (ref.) } \\
\hline Capital & $0,33 * * *$ & $1,41 * *$ & $1,32 * *$ & $0,64 * *$ & 1,26 \\
\hline \multicolumn{6}{|l|}{ Homem (ref.) } \\
\hline Mulher & $0,41 * * *$ & $0,70 * * *$ & $0,81 *$ & $0,69 * * *$ & 1,07 \\
\hline \multicolumn{6}{|l|}{ Cor branca (ref.) } \\
\hline Cor preta & 0,42 & $0,64 * *$ & 1,05 & 1,30 & 0,75 \\
\hline Cor parda & 0,82 & 0,84 & 1,01 & 1,06 & 0,81 \\
\hline Cor amarela & 0,00 & 1,15 & $2,34 * *$ & 0,62 & 0,78 \\
\hline Cor índio & 0,00 & 4,76 & $6,70 * * *$ & 2,10 & 0,00 \\
\hline Idade (anos) & $1,02 *$ & 0,99 & $0,99 * *$ & 1,00 & 1,00 \\
\hline \multicolumn{6}{|l|}{ Escol. analfabeto } \\
\hline Escol. primeiro grau completo & 1,09 & 1,24 & $1,52 *$ & 0,74 & 1,12 \\
\hline Escol. segundo grau completo & 1,41 & 1,05 & 1,29 & 0,84 & 0,79 \\
\hline Escol. ensino médio completo & 1,88 & 1,34 & $1,70 * *$ & 1,22 & 1,06 \\
\hline Escol. universitário completo & $4,96 * * *$ & $4,87 * * *$ & $3,34 * * *$ & $2,02 * *$ & 1,35 \\
\hline \multicolumn{6}{|l|}{ Estado civil casado (ref.) } \\
\hline Estado civil solteiro & 1,34 & 0,85 & 0,92 & $0,73 *$ & 1,00 \\
\hline Estado civil viúvo/separado & 1,45 & 1,22 & 1,31 & 1,16 & 0,81 \\
\hline \multicolumn{6}{|l|}{ Religião católica (ref.) } \\
\hline Religião evangélica & 0,79 & 0,91 & 1,00 & 0,88 & 0,78 \\
\hline Religião outra & $2,19 *$ & 1,24 & $1,72 * *$ & 1,06 & 0,92 \\
\hline Sem religião & 0,30 & 0,93 & $1,75 * * *$ & $0,40 * * *$ & 0,72 \\
\hline \multicolumn{6}{|l|}{ Renda classe E (ref.) } \\
\hline Renda classe D & 1,92 & 0,83 & 1,38 & 0,78 & 0,94 \\
\hline Renda classe C & 1,89 & 1,03 & $1,59 * *$ & 0,94 & 1,43 \\
\hline Renda classe A ou B & 2,09 & 1,16 & $2,45 * * *$ & $1,94 * *$ & $1,64 *$ \\
\hline \multicolumn{6}{|l|}{ Autoaval. classe perman. (ref.) } \\
\hline Autoaval. ascendeu & 1,30 & 0,93 & $1,71 * * *$ & $1,35 * *$ & 0,88 \\
\hline Autoaval. descendeu & 1,69 & 0,92 & 1,30 & 1,06 & 0,75 \\
\hline \multicolumn{6}{|l|}{ Não recebeu b. família (ref.) } \\
\hline Recebe bolsa família & 0,67 & $1,34 * *$ & 1,11 & 1,04 & 0,97 \\
\hline Constante & $0,00 * * *$ & $4,75 * * *$ & $0,13 * * *$ & $0,10 * * *$ & $0,23 * * *$ \\
\hline
\end{tabular}

Os asteriscos identificam o nível de significância dos respectivos coeficientes: * $(\mathrm{p}<0,1)$; ** $(\mathrm{p}<0,05)$; *** $(\mathrm{p}<0,01)$.

Fonte: Os autores, a partir do questionário do ESEB 2014. 
cujo estudo pioneiro de Duverger (1987) permitiu concluir que os ativistas filiados formavam o centro gravitacional dos partidos socialistas de massa. A segunda vertente, denominada de abordagem psicológica do voto, iniciada com a escola de Michigan em 1950, procurou demonstrar que o conceito de identificação partidária, aplicado aos cidadãos comuns, permitia compreender certos padrões de atitudes e comportamentos dos eleitores. Dessas abordagens examinamos dois conceitos fundamentais: a filiação a partidos políticos e a consistência da identificação partidária desses eleitores.

Embora esse trabalho tenha um caráter exploratório, os resultados encontrados a partir de análise dos dados do ESEB 2014 nos possibilitaram traçar o perfil dos eleitores que se declararam filiados (3\%) a um dos 12 partidos examinados, avaliar a consistência racional e/ou emocional e ideológica daqueles filiados que se dizem identificar com um desses atores partidários, e, finalmente, testar o poder explicativo dos conceitos da filiação e identificação partidária sobre o comportamento dos cidadãos.

No que diz respeito ao perfil dos eleitores que se auto-identificaram como sendo filiados, verificamos que esses estão desigualmente distribuídos pelo território nacional, havendo maior concentração de filiados nas regiões Sul e Nordeste e no interior dos estados e padrões mais baixos de filiação no Sudeste. Esse resultado, contraditório com as abordagens clássicas da teoria da modernização e do marxismo, foram parcialmente confirmadas por Speck (2013) que também demonstrou, com relação aos dados sobre filiação do TSE, que as taxas de filiação são maiores quanto menor o município. O que também nos leva a especular que, em determinados contextos, os processos de filiação e demais vínculos partidários podem estar associados mais intensamente a relações de proximidade interpessoal do que indicam as teorias clássicas da identificação partidária.

A maior parte dos filiados é formada por homens brancos, na faixa etária dos 41 a 64 anos, com nível universitário e, em sua maioria, estão separados. São também eleitores que avaliaram que em boa medida sua posição econômica na sociedade melhorou. Esses apresentaram maior proximidade e empatia com os partidos. Em contraposição, entre os eleitores que acreditam que a posição socioeconômica não mudou estão as menores taxas tanto de filiados quanto de aproximação e empatia com os partidos políticos.

Já no que se refere à identificação partidária, avaliada por meio das taxas de proximidade e de empatia, notamos que os eleitores residentes nas regiões Nordeste apresentam padrões mais altos, enquanto os que habitam o CentroOeste e Sudeste estão menos identificados com os partidos. Padrão semelhante foi observado também na comparação entre a capital e o interior dos estados. Vimos ainda que são os homens que tendem apresentar maiores taxa de identificação partidária. Embora outras pesquisas devam ser realizadas para explicarmos os padrões identificados, supomos que esses comportamentos possam estar relacionados às características da competição para os diversos pleitos em cada estado, bem como ao nível de informação política dos cidadãos entrevistados.

Ao traçarmos esse perfil dos filiados e simpatizantes dos partidos examinados e avaliarmos a consistência interna dos conceitos de filiação e identificação, os resultados alcançados nos levaram a ter mais segurança do significado substancial dos conceitos que estamos testando, contradizendo parte da literatura especializada sobre organizações partidárias e processos eleitorais no Brasil, cuja suposição é a de que a filiação seja um fenômeno formal, desprovido de significado para os filiados. Ainda nessa direção, nossos achados divergem do diagnóstico de que a identificação partidária seria inexistente ou teria um alcance limitado em um país onde as organizações partidárias são ainda muito 
jovens para que cultivem lealdades e laços de identidade mais estáveis com o eleitorado. Ao contrário dessas previsões sem base empírica, verificamos uma realidade bem mais complexa e heterogênea quando focamos nossas lentes na amostra de filiados entrevistada pelo ESEB 2014.

Um primeiro resultado digno de nota foi que o grupo de filiados com identificação congruente (aqueles que gostam e votam no mesmo partido) envolve apenas metade desse contingente. $\mathrm{O}$ que nos levou a salientar que a filiação partidária é, pelo menos parcialmente, um fenômeno com conteúdo racional e emocional. Contudo, um entre cada quatro filiados não gosta de nenhum partido (21\%), enquanto outros $29 \%$ gostam de outro partido. Isto é, metade dos que se declaram filiados não o fazem, aparentemente, por causa do partido. O que significa que não podemos avaliar toda filiação como expressão de um compromisso mais intenso com certo partido.

Outras importantes diferenças de significado foram constatadas quanto à densidade da filiação e da identificação partidária em relação aos três grupos de partidos distribuídos pelo espectro político ideológico. Como vimos em relação à intensidade da empatia, os partidos de esquerda ocupam dois terços do espectro (65\%), os partidos de centro representam um terço $(31 \%)$ e os de direita ocupam apenas $4 \%$. Esses dados confirmaram, portanto, que é nos partidos de esquerda que encontramos mais compromisso de seus filiados. Já nos partidos de centro e direita, a identificação é mais tênue. Essas diferenças são reforçadas quando agregamos os resultados da análise das relações contraditórias (identificação de um partido como mais próximo, mas avaliação melhor de outro partido) e verificamos que os partidos de centro e direita igualmente apresentam índices maiores de contradição (37\% e 50\%, respectivamente) contra $16 \%$ nos partidos de esquerda.

Em contrapartida, em relação aos filiados a distribuição é mais equilibrada, ou seja, dois em cada cinco filiados o são a partidos de esquerda, um a partidos de centro e outros dois a partidos de direita. Contudo, em relação à proximidade dos filiados com os partidos, outras diferenças emergem quando comparamos esses grupos. Verificamos que a parcela dos filiados dos partidos de esquerda que não tinha nenhuma relação afetiva com os partidos políticos era pequena (13\%), mas ela cresceu nos partidos de centro (21\%) e direita (27\%). Já os filiados que gostam muito do partido representaram metade dos filiados aos partidos de esquerda, mas somente $25 \%$ dos filiados nos partidos de centro e de direita.

Finalmente, testamos o poder explicativo dos conceitos de filiação e identificação partidárias sobre o comportamento e atitudes políticas dos cidadãos. A primeira constatação importante foi que, em comparação com os cidadãos que não gostam de nenhum partido, os que gostam de um partido têm mais chances de filiação. Esse comportamento, por sua vez, é influenciado pela região, gênero e grau de instrução. Outro dado digno de nota foi a constatação de que os filiados com maior identificação partidária apresentam maior conhecimento político. Ainda verificamos que a filiação e a identificação partidária aumentam as chances do eleitor apresentar maiores taxas de associativismo. Por fim, demonstramos que a identificação partidária contribui para explicar os padrões de votação em candidatos da mesma sigla partidária para diferentes cargos.

Um achado não trivial desse estudo exploratório é que a filiação não é um formalismo burocrático, desprovido de significado e de consequências para o comportamento político dos filiados. Futuras pesquisas terão que aprofundar a questão do significado da filiação e da identificação partidária no Brasil, inserindo a pesquisa sobre os partidos no eleitorado brasileiro no debate sobre partidos nas novas democracias. 
Finalmente, não podemos ignorar que um resultado aparentemente contraditório abre uma nova frente de investigações futuras. Ele se refere aos filiados incongruentes/contraditórios, isto é, ao fenômeno dos vínculos conflitantes de cidadãos brasileiros com múltiplos partidos. Não temos informação atualmente para solucionar esse problema, mas podemos levantar hipóteses que nos permitam avançar por meio de novos surveys, com foco específico no universo dos filiados a partidos no Brasil.

Acreditamos que o ponto de partida para explicar essa outra metade do universo de filiados a partidos no Brasil é admitir que o conceito de identidade partidária explica apenas parcialmente os tipos de vínculos entre cidadãos e partidos. Como demonstrou Speck (2013), baseado em dados de filiação disponibilizados pelo TSE, a variação da taxa de filiados parece estar relacionada ao ciclo eleitoral municipal, especialmente antes das convenções anteriores às eleições. Além disso, segundo o mesmo autor, a variação da taxa de filiações está diretamente relacionada ao aumento do número de candidaturas a vereador, especialmente nos municípios menores do que 200 mil habitantes. Isso indica que, no caso das filiações realizadas por diretórios municipais, a motivação principal dos filiados é participar no processo das eleições, seja apoiando uma candidatura no processo de seleção interna pelo partido, seja na condição de candidato concorrendo nas eleições. Portanto, os indicadores de filiação por proximidade e/ou afetividade ao partido não explicam isoladamente as motivações para os cidadãos se filiarem a partidos. Provavelmente, aqueles que afirmam não gostar/não ter proximidade com os partidos aos quais estão filiados, mantém algum tipo vínculo pessoal com um cabo eleitoral, candidato ou político eleito pelo partido.

Por outro lado, Amaral (2014) com base em um survey com filiados aos principais partidos do estado de São Paulo, demonstrou que as principais motivações para a filiação são: "convicções políticas"; "o gosto pela convivência e as atividades da vida partidária" e a "tradição de envolvimento familiar com a política". Outra dimensão explorada foi o tipo de recrutamento. Os dados são claros ao apontar os amigos/família como o principal canal de recrutamento pelos maiores partidos paulistas. Em seguida, estariam o convite de representantes partidários e o contato com políticos eleitos. Parece claro que o primeiro motivo está fortemente relacionado ao fenômeno da identificação partidária (especialmente a emocional, mas, também, a racional), mas as duas outras motivações também podem ser associadas a motivações interpessoais e/ou pragmáticas.

Quando relacionamos os dados do ESEB 2014 com esses estudos, o universo dos filiados a partidos políticos parece se configurar em dois grandes conjuntos de motivações, formas de recrutamento, assim como práticas político-partidárias. De um lado, como mostrou nossa análise dos resultados do ESEB 2014, parte significativa dos filiados apresenta perfil consistente com as abordagens tradicionais da identificação partidária (por proximidade e/ou afetividade), mobilizados por convicções políticas e recrutados através de redes associativas, políticas (ou mesmo interpessoais), além das relações familiares. Esses parecem ser, como mostrou nossa análise, e confirmando pesquisas anteriores, predominantemente vinculados a partidos de esquerda, mesmo os mais moderados. De outro, encontramos um resultado aparentemente contraditório, pelo menos com relação ao paradigma clássico da identificação partidária como única motivação para a filiação a partidos. Esse é um universo ainda relativamente desconhecido, ou ignorado, revelado de forma bastante contundente pela nossa análise dos dados do ESEB 2014. São cidadãos que se mobilizam politicamente, por vínculos afetivos e/ou racionais a políticos profissionais e/ou lideranças associativas (sindicais, religiosas, corporativas etc.), mas não a partidos ou programas/ideologias partidárias. Aparentemente, são 
recrutados por redes de relações interpessoais (amigos/familiares, políticos conhecidos, lideranças carismáticas etc.) e atuam no âmbito partidário, vinculados predominantemente ao ciclo eleitoral e às candidaturas/carreiras dos políticos profissionais (e seus cabos eleitorais) e lideranças associativas e/ou carismáticas. Daí não demonstrarem proximidade e/ou afetividade com relação ao partido ao qual se encontram filiados, pois sua identificação política parece estar assentada em vínculos interpessoais, ou mesmo associativos (religiosos, especialmente), mas extra-partidários. Aprofundar o conhecimento sobre esse universo será um desafio para futuras pesquisas.

Bruno Wilhelm Speck (bruno.speck@gmail.com) é Doutor em Ciência Política pela Albert-Ludwigs-Universität Freiburg (Freiburg/Alemanha) professor do Departamento de Ciência Política da USP. Vínculo Institucional: Departamento de Ciência Política, Universidade de São Paulo, São Paulo, SP, Brasil.

Maria do Socorro Sousa Braga (msbraga2009@gmail.com) é pós-Doutora em Ciência Política pela USP e professora do Programa de Pós-Graduação em Ciência Política da UFSCar. Vínculo Institucional: Departamento de Ciências Sociais, Universidade Federal de São Carlos, São Carlos, SP, Brasil.

Valeriano Costa (vmfc@ unicamp.br) é Doutor em Sociologia pela USP e professor do programa de Pós-Graduação em Ciência Política da Unicamp. Departamento de Ciência Política, Universidade Estadual de Campinas, Campinas, SP, Brasil.

\section{Referências}

Amaral, O., 2014. Por dentro das bases partidárias: Uma análise do perfil dos filiados a partidos políticos no estado de São Paulo. In Instituto de Iberoamerica, Salamanca.

Biezen, I.; Mair, P. \& Poguntke, T., 2012. Going, going, . . . gone? The decline of party membership in contemporary Europe. European Journal of Political Research, 51(1), pp.24-56. DOI: 10.1111/j.1475-6765.2011.01995.x

Blais, A.; Gidengil, E.; Nadeau, R. \& Nevitte, N., 2001. Measuring Party Identification: Britain, Canada, and the United States. Political Behavior, 23(1), pp.5-22. DOI: 10.1023/A:1017665513905

Braga, M.S.S. \& Pimentel Jr., J., 2011. Os partidos políticos brasileiros realmente não importam? Opinião Pública, 17(2), pp.271-303. DOI: 10.1590/S0104-62762011000200001

Campbell, A.; Converse, P.; Miller, W. \& Stockes, D., 1960. The American Voter. New York: Willey.

Carreirão, Y. \& Kinzo, M.D., 2004. Partidos políticos, preferência partidária e decisão eleitoral no Brasil (1989-2002). Dados, 47(1), pp.131-168. DOI: 10.1590/S0011-52582004000100004

Duverger, M., 1987. Os partidos políticos. Rio de Janeiro: Editora Guanabara.

Kinzo, M.D., 2005. Os partidos no eleitorado: percepções públicas e laços partidários no Brasil. Revista Brasileira de Ciências Sociais, 20(57), pp.65-81. DOI: 10.1590/S0102-69092005000100005

Kinzo, M.D. \& Braga, M.S.S, eds. 2007. Eleitores e representação partidária no Brasil. São Paulo: Humanitas.

Manin, B., 2013. A democracia do público reconsiderada. Novos Estudos, 97, pp.115-127. DOI: 10.1590/S0101-33002013000300008

Norris, P., ed., 1999. Critical Citizens: Global Support for Democratic Government. Oxford: Oxford University Press.

Pizzorno, A., 1966. Introduzione alio Studio della Partecipazione Politica. Quaderni di Sociologia, 15(3-4), pp.261-278.

Rennó, L., 2011. Validade e confiabilidade das medidas de confiança interpessoal: o Barômetro das Américas. Dados, 54(3), pp.391-428. DOI: 10.1590/S0011-52582011000300005

Samuels, D., 2008. A evolução do petismo (2002-2008). Opinião Pública, 14(2), pp.302-318. DOI: 10.1590/S0104-62762008000200002

Samuels, D. \& Zucco Jr., C., 2010. The Roots of Petismo, 1989-2010. In Meeting of the American Political Science Association. Washington, D.C.

Scarrow, S., 2015. Beyond Party Members. Changing approaches to partisan mobilization. Oxford: Oxford University Press.

Scarrow, S. \& Gezgor, B., 2010. Declining Memberships, Changing Members? European political party members in a new era. Party Politics,16(6), pp.823-843. DOI: 10.1177/1354068809346078

Singer, A., 2009. Raízes Sociais e Ideológicas do Lulismo. Novos Estudos, n.85, pp.83-102. DOI: 10.1590/S0101-33002009000300004

,2012. Os sentidos do lulismo: reforma gradual e pacto conservador: São Paulo: Companhia das Letras.

Soares, G.A.D., 1982. A política brasileira: novos partidos e velhos conflitos. In D. Fleischer, ed. Da distensão à abertura. As eleições de 1982. Brasília: Editora da UNB.

Speck, B.W., 2013. Nem ideológica, nem oportunista: A filiação partidária no contexto pré-eleitoral no Brasil. Cadernos Adenauer, 14(2), pp.37-60. 
Thomassen, J., 1994. Introduction: The intellectual history of election studies. European Journal of Political Research, 25(3), pp.239-245. DOI: 10.1111/j.1475-6765.1994.tb00419.x

Van Haute, E. \&Gauja, A., 2015. Party Members and Activists. London: Routledge.

Veiga, L.F.,2007. Os partidos políticos na perspectiva dos eleitores: mudanças e continuidades na identificação partidária e na avaliação das principais legendas após 2002. Opinião Pública, 13(2), pp.340-365. DOI: 10.1590/S0104-62762007000200005

,2011. O partidarismo no Brasil (2002/2010). Opinião Pública, 17(2), pp.400-425. DOI: 10.1590/S0104-62762011000200005

Venturi, G., 2010. PT 30 anos: Crescimento e mudanças na preferência partidária impacto nas eleições de 2010. Revista da Fundação Perseu Abramo, 5.

\begin{abstract}
We discuss two different traditions of studying party membership and party identification in political science. We then apply these concepts exploring the data of the ESEB 2014 (Election Survey for Brazil). First we describe the data on party membership and party identification, exploring different social cleavages in Brazil. Then we test to what extent party membership and party identification help explain political attitudes and behavior of citizen in Brazil. Three different types of party membership emerge from this analysis: members without emotional bond to any party; those identifying emotionally with their party (50\%); and a third group holding membership but feeling closer to a different party. These results demand future research into the meaning of party membership in Brazil. Party identification in Brazil should not be overlooked. It is a concept that allows predicting party membership and different forms or political activism. It also moderately explains political participation in elections. We conclude that party membership and party identification, which have not earned much attention in the study of Brazilian politics, are useful concepts showing internal consistency and structuring political attitudes of citizen and help explain their behavior. Both phenomena deserve attention in future research.
\end{abstract}

KEYWORDS: Party affiliation; Party identification; Political parties; Political participation; Election studies.

License information: This is an open-access article distributed under the terms of the Creative Commons Attribution License (CC-BY-NC 4.0), which permits unrestricted use, distribution, and reproduction in any medium, provided the original work is properly cited. 